Western University

Scholarship@Western

Economic Policy Research Institute. EPRI Working

Papers

Economics Working Papers Archive

2008

2008-3 Closing the 49th Parallel: An Unexplored Episode in Canadian Economic and Political History

James B. Davies

Stanely L. Winer

Follow this and additional works at: https://ir.lib.uwo.ca/economicsepri_wp

Part of the Economics Commons

Citation of this paper:

Davies, James B., Stanely L. Winer. "2008-3 Closing the 49th Parallel: An Unexplored Episode in Canadian Economic and Political History." Economic Policy Research Institute. EPRI Working Papers, 2008-3. London, ON: Department of Economics, University of Western Ontario (2008). 


\title{
Closing the 49th Parallel: An Unexplored Episode in Canadian Economic and Political History
}

\author{
by
}

James B. Davies and Stanley L. Winer

Working Paper \# 2008-3

December 2008

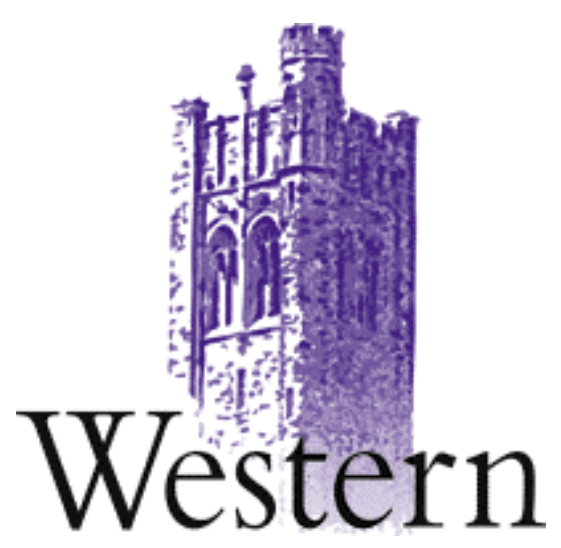

\section{RBC Financial Group Economic Policy Research Institute EPRI Working Paper Series}

\author{
Department of Economics \\ Department of Political Science \\ Social Science Centre \\ The University of Western Ontario \\ London, Ontario, N6A 5C2 \\ Canada
}

This working paper is available as a downloadable pdf file on our website http://economics.uwo.ca/centres/epri/ 


\title{
Closing the 49th Parallel: An Unexplored Episode in Canadian Economic and Political History
}

by

\author{
James B. Davies* and Stanley L. Winer**
}

June 20, 2008

\begin{abstract}
We draw attention to, and begin to consider the implications of the severe restrictions on emigration by Canadians to the United States introduced under the U.S. Immigration Act of 1965. These restrictions came into effect in 1968 and lasted until mobility began to increase under the free trade agreements in the early 1990's. This is an unusual episode in Canadian history, one whose implications for public policy have received little attention.

The near closing of the border during this period likely led to a decrease in the elasticity of labour supply in Canada. We derive the implications of such a change in a competitive political model where the political costs and benefits of levying taxes on different activities are distinguished. Increased reliance on, and changes in the structure of, labour income taxes, and an increase in the size of the public sector are predicted. We show that these predictions are consistent with what occurred over the two decades after the near closing of the U.S. border.
\end{abstract}

We are indebted to Stephen Ferris for helpful comments.

* University of Western Ontario. (jdavies@uwo.ca)

** Carleton University (stan_winer@carleton.ca). Corresponding author. 


\section{Introduction}

The purpose of this paper is to draw attention to, and begin to consider the possible implications for Canada of the near closing of the Canada-U.S. border to emigration in the late 1960's. This closure resulted from a radical change in immigration regulations affecting Canada that came into force in 1968 under the U.S. Immigration Act of 1965. The period of near closure lasted until the mobility provisions of the free trade agreements began to have their effect in the early 1990 's. Historically this is an unusual episode in economic and social relations between Canada and the United States, one whose implications for Canadian public policy have received little attention.

There is a striking association between changes in fiscal structure in Canada and the timing of the U.S. decision to close the border in the mid 1960's. Whether there has been an important causal relationship between the openness of the border and Canadian public policy is, in our view, an interesting question that has not yet been asked. We pose that question and explore how it may be answered.

In the late 1950's the total size of government in Canada was not much different from that in the U.S.. As shown in Figure 1 (from Ferris and Winer 2007), comprehensively and comparably defined government spending as a fraction of GDP stood at slightly over $28 \%$ in both the U.S. and Canada. ${ }^{1}$

[Figure 1 here]

As Figure 1 also illustrates, total government spending as a fraction of GDP in Canada began to diverge substantially from its U.S. counterpart in the 1960s. In quick succession we saw the introduction of the Canada and Quebec pension plans (1965), lowering of the Old Age Security age of eligibility to 65 (gradually implemented beginning in 1965), the onset of Medicare under the Medical Care Act of 1966, and the introduction of the Guaranteed Income Supplement, also in 1966. Other spending programs also increased, and in 1971 the Unemployment Insurance eligibility rules were relaxed and benefits raised. By 1980, before the serious recession in Canada, the total size of government in Canada was different than in the U.S. Consolidated allgovernment comprehensively defined spending stood at about $38 \%$ of GDP in Canada versus $35 \%$ in the United States. Non-defense spending was 36\% in Canada versus about $29 \%$ in the U.S., a gap of about 7 percentage points, which was two percentage points of GDP higher than the same gap in 1960. Taxes were also higher in Canada, although not as high as they needed to be to balance budgets. Thereafter, the two public sectors diverged even more in size until the peak of what Ferris and Winer (2007) call the bulge in comparative spending was reached in 1992.

The increase in government spending in Canada in the 1960's and 70's is a familiar story. What is not so familiar is that this period coincided with an almost complete closure of the Canada U.S. border to migration. Both countries terminated their longstanding "hemispheric

\footnotetext{
${ }^{1}$ These and subsequent figures concerning the size of government are from Ferris and Winer (2007) and their spreadsheet at www.carleton.ca/ winers. Here comprehensively defined government refers to a consistent treatment of nonprofit hospitals and post-secondary education in the two countries.
} 
exemptions" to immigration quotas, which had allowed qualified immigrants born in the Western Hemisphere to enter both countries without numerical limit.

Canadians were not entirely locked out of the U.S. They could still travel there freely for vacation and business purposes. But visas had long been required for permanent resettlement (see Ramirez, 2001), and under the 1965 U.S. Immigration Act, beginning on July 1, 1968 Canadians had to compete for an annual total of 120,000 visas for the whole of the Western Hemisphere. $^{2}$ Labour certification rules were also tightened up sharply by the 1965 Act, making it more difficult for Canadian workers to obtain clearance to take jobs in the US (Tomasi and Keely, 1975, pp. 8,9). Canada's immigration reform of 1962, under which the preferred class of origin countries, which had included the US, was abolished, had a similar effect on U.S. immigrants to Canada, whose entry was further affected by the implementation of our points system on Oct. $1,1967 .^{3}$

The new immigration system in the United States, and the abolition of the hemispheric exemption for migrants in both directions between Canada and the United States represented an important regime change. Coinciding with this change there was a sharp fall in emigration from Canada to the US. (See Figure 2.) While emigration had been relatively high from 1960 to 1965, averaging 48,345 official migrants per year, the flow crashed after 1968, reaching a trough of 11,215 in 1975. Taking a longer view, emigration to the U.S. from Canada in the two decades 1951-60 and 1961-70 averaged 39,563 persons annually. The numbers fell to 16,994 per year from 1971 to 1980 and then to 15,694 from 1981 to 1990 .

[Figure 2 here]

There are a variety of special reasons why Canadians may have been less interested in moving south in the late 1960s and 1970s than formerly: real wages rose in Canada; there was civil unrest in U.S. cities; and young men wanted to avoid being drafted to fight in Vietnam. However, these factors had largely ceased to operate by the 1980s. The continued low rate of migration from Canada to the United States after the War in Vietnam and U.S. civil disturbances were well over, and in the teeth of high unemployment in Canada during and after the 1981-82 recession, appears to confirm the effectiveness of the new restrictions on migration from Canada to the U.S. imposed by the 1965 U.S. Immigration Act.

While the period of strong restrictions on Canadian emigration to the U.S. did not come to an end until the HB-1 and TN temporary visas came into wide use after 1990 under the Free Trade Agreement (FTA) and its successor, the North American Free Trade Agreement (NAFTA), there were some relevant changes in U.S. regulations. In October 1978 the separate hemispheric limits were abolished in favor of a single worldwide annual limit of 290,000 - equal to the sum of the former hemispheric limits. This global limit was reduced to 280,000 in 1980 and 270,000 in 1981, indicating a tightening of immigration restrictions. That policy was reversed by the 1990 Immigration Act, however, which raised the annual limit. By 1998 the global annual limit had risen to 366,000 . This change in U.S. policy on permanent immigration has reinforced the role

\footnotetext{
${ }^{2}$ This Act introduced a system of preference classes, emphasizing family reunification and skill priorities. However, the preference classifications were not applied to Western Hemisphere immigrants until 1976.

${ }^{3}$ See Green (1995) for a concise outline of changes in Canadian immigration policy over time.
} 
of temporary migration under the FTA and NAFTA in increasing cross-border labour mobility.

To continue our analysis of the consequences of the closing of the border in 1968, we proceed as follows. In section two, we consider the possible consequences for Canadian fiscal structure, including the tax mix, the structure of marginal tax rates and the size of government, as well as effects on the before and after-fisc distributions of income. We make use of a model of fiscal structure in a competitive political system in this investigation. In section three we turn to the free trade era when the closing of the border was partially reversed, and then in a fourth section we open the discussion to a broad set of factors that may need to be taken into account in any comprehensive assessment. A fifth section sets the closing of the border in 1968 in its wider historical context with respect to experience in Canada, with respect to migration from Europe to the United States in the 20th century, and within the European Union in recent decades. Here we also speculate about the implications of the analysis for future migration policy vis a vis the United States. A final section summarizes the arguments of the paper.

\section{Possible Effects of the Change in Migration Regime on Public Policy}

Why is it interesting that the beginnings of what Ferris and Winer (2007) call the bulge in comparative growth of all (consolidated) government spending in Canada and the U.S. appears to roughly coincide with closing of the border to migration? The closing of borders to migration can result in a sharp reduction in the elasticity of labour supply. When its supply is highly elastic, labour does not sit still to bear new taxes thrust upon it. Less labour is supplied, and with an open border much of the reduction in labour supply may take the form of emigration. Higher taxes on labour will be partly shifted onto consumers and owners of immobile factors such as land or natural resources. As labour leaves the country, GDP may fall. All of these negative consequences of tax increases must be, and usually are, carefully balanced by any government against the benefits of increased tax revenues. The result is likely to be a lower equilibrium level of taxation and government spending than with a closed border, as we now explore more formally.

\subsection{A basic model of a fiscal system in a competitive political equilibrium}

A simple graphical exposition of a model of the tax mix in a democracy, based on Hettich and Winer $(1988,1999)$ and Kenny and Winer (2006) is helpful in exposing the implications for tax structure and the size of government of closing the border to emigration. Fiscal structure in this model is a political equilibrium, one that reflects a continual balancing of opposing interests in the pursuit of political support and electoral success.

Assume that the incumbent party's sole objective is to get re-elected and that it pursues this aim by maximizing total expected support from a heterogeneous electorate. The probability of support from any voter is influenced positively by the provision of public goods and is affected negatively by the full cost of raising the revenues required to finance public services.

Taxation affects voters in two basic ways. First, disposable income is reduced. In addition, there is a welfare loss linked to economic adjustments made in response to taxation. We shall refer to 
the sum of these effects as the loss in full income and assume that opposition to, or the political cost of, taxation is positively related to the loss of full income. Individuals vary in several respects that are relevant to the full effects of taxation on them and to their political opposition to taxation. They differ with respect to the taxable activities they undertake, in their willingness to substitute between taxable (and other) activities in order to escape taxation, and in their costs of organizing political opposition. In addition, they have varying evaluations of public output, which affect the total marginal political benefits from changing the level of the public good.

Given these assumptions, it is then possible to illustrate the government's choices concerning the level of public output and the taxation of different activities using Figure 3. The figure depicts a simple case where there are only two taxable activities engaged in by taxpayers and one pure public good on which all tax revenues are spent. We may imagine the taxable activities to be employment income, and income from capital. Each tax base has associated with it a unique "Laffer curve" or tax rate - revenue relationship, as well as a different evaluation by the voters of the full cost of a given tax payment. ${ }^{4}$

\section{[Figure 3 here]}

The rate applied to each base with its associated loss in full income for taxpayers is translated into marginal political opposition by the marginal political cost functions in the upper half of the panels corresponding to the two tax bases, where marginal political cost is expressed per dollar of revenue raised. As shown by curves through the points labeled as "1", marginal political cost per dollar functions differ across the two bases, reflecting differences in how voters evaluate the economic effects of taxation levied on each activity, and on how these evaluations are translated into political opposition.

The third panel on the right side of Figure 3 shows the determination of budget size, with the total marginal political cost per dollar curve representing the horizontal addition of marginal political cost functions from the other two panels. Total marginal political benefit per dollar for the society, equal to the vertical sum of individual marginal political benefit functions, also expressed per dollar of revenue, is given by the downward sloping curve. The desired budget in the initial situation is at point 1 , where the total marginal political benefit equals the total marginal political cost. ${ }^{5}$

The implications of the equilibrium for the structure of the fiscal system are readily understood if we realize that decision makers who maximize support will minimize total political costs for any given level of revenue collected. This requires that marginal costs per dollar of revenue be equalized across tax bases. Any government will then tax both activities and will do so at generally different tax rates. One such equilibrium is represented in Figure 1 by points labeled "1" with associated tax sources, tax rates $t_{A}$ and $t_{B}$ and government size $R_{1}$.

\footnotetext{
${ }^{4}$ Figure 3 is drawn on the additional assumptions that each Laffer curve can be drawn independently of taxation levied on the other base, as well as on the assumption that political support is separable in political benefits from public output and opposition to taxation. A more formal mathematical treatment does not require these assumptions. See Hettich and Winer (1999, chapter 4).

${ }^{5}$ Note that individual marginal political benefit functions do not count in the determination of the equilibrium size of government; only their sum matters because of the nature of the public good.
} 
Now let us consider the effects of closing the Canada - U.S. border to emigration. Such a shock will initially alter the Laffer curve for the employment income tax base which will now shift outwards and turn backwards at a higher tax rate than before, reflecting the fact that labour supply is, to a greater extent, now bottled up in the domestic economy and so has become more inelastic to the Canadian economy as a whole. The result of closing the border to emigration is that any given amount of personal income tax revenue can now be collected using a lower tax rate so that, at any given level of revenue, the loss in full income and hence the opposition to taxation will be reduced. The reduction in opposition is shown in panel A of Figure 3 by a downwards shift in the marginal political cost function associated with this tax source. The aggregate marginal political cost curve in panel $\mathrm{C}$ shifts down and as a result, and as shown in the figure, equilibrium will be reestablished only after political competition leads the incumbent party to rely more heavily on employment income taxes and less on capital income taxes, while the size of government is increased.

In the real world not all taxes can be neatly divided into those on employment income and those on capital income. This affects how one attempts to test the above predictions. In Canada, capital income is sheltered from personal income tax in important ways, so that personal income taxation (PIT) may be treated (approximately) as a tax on employment income. The PIT is the most important form of tax on employment income, but Canada and Quebec pensions and unemployment contributions (UI/EI), as well as other payroll taxes, should of course not be forgotten. Corporate income tax and property taxes may be thought of, roughly, as taxes on capital income. ${ }^{6}$

\subsection{Corroborating fiscal history}

Canadian fiscal history is, at least at first glance, consistent with the story told above: a shift in the tax mix towards increased reliance on taxation of employment income along with reduced reliance on other forms of taxation, and general government growth.

Table 1 illustrates the dramatic increase in reliance on the personal income tax - the tax that most directly affects mobile suppliers of labour services. Between 1960 and 1970, relative reliance on this tax rose in Canada from just over 20 percent of total tax revenue to just under 35 percent. Taking into account social insurance taxes levied to finance a pay-as-you-go Canada and Quebec pension as well, the increase in taxation of employment incomes amounts to almost a doubling (from 21.21 per cent to 41.2 percent) over the decade.

[Table 1 here]

The second panel in Table 1 shows that, as a per cent of GDP, reliance on personal income and social security taxes increased from 5.1 per cent to 12.2 per cent, while total taxes in GDP increased from 23.7 to 29.3 per cent. At the same time, reliance on corporate, various indirect and local taxes fell from 18.6 to 16.2 per cent of GDP.

\footnotetext{
${ }^{6}$ Canada has also had explicit taxes on corporate capital at times, at both the federal and provincial levels. Sales taxes on business inputs may also be thought of, approximately, as a tax on capital income.
} 
The movement of tax rates reinforces the story we are telling. In Figure 4 we can see that average marginal personal income tax rates - an important indicator of the tax disincentive for labour supply - increased quickly after 1965. Marginal tax rates on very high income earners also increased in the five years or so after the coming closure of the border was announced.

[Figure 4 here]

Growth of total government spending relative to that in the United States following the sharp decline in emigration to the U.S. is seen in Figure 1, as we noted earlier. But this figure also suggests that government size has been increasing over the decades since the Second World War. To see more clearly if emigration to the U.S. in involved, in principle we should construct a regression model that accounts for major sources of government growth in addition to migration. In the Appendix, we provide a preliminary statistical analysis of the growth of government for various sample periods from 1900, using equations for the longer run trend in government size of the type suggested by Ferris, Park and Winer (2008). These equations indicate that the size of the federal public sector in Canada may indeed have increased when emigration to the U.S. declined. $^{7}$

We shall return to the fiscal consequences of the closing of the border below.

\subsection{Effects of closing the border on the distribution of income}

In part because of its effects on the fiscal system, altering labour mobility may affect both the after-fisc and the before-fisc distributions of income. A consideration of these effects provides ancillary evidence about the consequences of the closing of the border. We consider, first, the implications for the distribution of income after the net impacts of the fiscal system are accounted for.

As we have pointed out earlier, closing of the border coincided with a shift toward greater reliance on personal income taxation and a higher degree of tax progressivity. This will tend to equalize the after-fisc distribution of income to some extent. For a full analysis of fiscal impacts on the distribution of real income one should also consider the likely distributional pattern of increased government spending. It is consistent with the spatial voting model introduced earlier to predict that increased spending will be done in the way that maximizes political support. Under plausible assumptions, this may be achieved through a progressive pattern of government spending, so that any increase in government spending that occurs when the border is closed will also have a progressive incidence and consequently will reduce income inequality to some extent. Public spending increases in the decade or so after 1965 were indeed focused on a number of inherently progressive transfer programs: public pensions, old age security, Medicare, unemployment insurance and other benefits for low income families, families with children, and seniors.

7 A statistical model of the evolution of tax structure remains to be constructed. But we leave this research for another paper. For ideas about how a statistical model of tax structure might be constructed, see Hettich and Winer (1999, chapter 10) and Kenny and Winer (2006). 
While it appears that the overall budgetary incidence of the Canadian tax-transfer system (excluding consideration of the consequences for individual incomes of public goods and services) did not change much from 1960 to 1980 - see Vermaeten et al. (1995) - it is also clear from existing empirical work that personal transfer payments are highly progressive elements in the fiscal system as a whole. It seems reasonable to suspect, then, that the border closing may have resulted in a fiscal system that was more equalizing than it otherwise would have been.

What about the before-fisc distribution of income? With a closed border labour markets in Canada and the U.S. are severed and there is much less reason to expect wage equalization. While the classic Heckscher-Ohlin model of international trade would predict that labour immobility would not interfere with factor price equalization, in the real world large departures from factor price equality are often observed across borders where there is imperfect factor mobility. (See for example, Harris and Schmitt, 2005.) We should therefore expect that in a period with severe limits on Canada-U.S. labour mobility, the distributions of wages and salaries in the two countries would become less similar. This is in fact what happened.

In the period from 1965 to the late 1990s before-tax income inequality rose in the U.S. more or less continuously, and at a rapid pace. The Gini coefficient for family income before tax stood at 0.356 in 1965 and 0.433 in 2000, according to the Current Population Survey (CPS). In Canada, there was a much weaker upward trend in before-tax inequality. The Gini for family income before tax rose from 0.326 in 1965 to just 0.354 in $2000 .^{8}$ It seems plausible that the relative similarity in before-tax inequality between Canada and the U.S. in 1965 may have owed something to the longstanding fairly open border between the two countries, while the subsequent divergence in inequality was enhanced by the disconnection of the Canada and U.S. labour markets after 1965, and by the fiscal developments concerning tax rate progressivity and personal transfer payments discussed earlier.

Consideration of the relative supply of, and consequences of educated labour may also help to understand why income before-fisc inequality stayed roughly constant in Canada at the same time that is was rising in the U.S.? Both countries were exposed to much the same technological changes and international trade influences. But they have different demographic patterns and have experienced different trends in education and training. After 1965 there was a very large increase in the education attainment of Canadians as each new cohort went through the education system. Compared to this bulge in training, there was little change in the U.S. (Murphy et al., 1998)

With labour markets disconnected, this meant an increase in the relative supply of more educated workers in Canada, which would have depressed the earnings of the more educated, moderating income inequality. Empirical work on the impact of education trends on wages in Canada indicates that this mechanism was indeed at work. (Again, see Murphy et al., 1998.)

\footnotetext{
${ }^{8}$ For U.S. Gini coefficients see Table F-4 at http://www.census.gov/hhes/www/income/histinc/f04.html viewed on Jan. 15, 2008. For Canada in 1965 see Love and Wolfson (1976) Table 5, and for 2000 see Statistics Canada (2002) Table 7.3.
} 


\section{The Free Trade Era and the Consequences of the Partial Reopening of the Border}

Under the U.S. Immigration Act of 1985 the limits on the number of immigrants to the U.S. each year were significantly loosened. Then in 1989 the Canada - U.S. free trade agreement, under which new classes of temporary migrants were created, came into force. Under this agreement, and its successor NAFTA, which came into force in 1994, it was possible for workers with the required qualifications (usually a Bachelor's degree suffices) in a list of specified occupations to enter the US on a temporary visa. Under NAFTA the most important visa type has been the TN1 , which is issued for one year only but which can be renewed indefinitely for further one-year periods. There was, accordingly, a large increase in the number of "temporary" migrants from Canada to the US after 1990. DeVoretz (1998, Table 3) reports that the flow of Canadian nonimmigrant professionals and their family members rose from 2,817 in 1989, the first year of the FTA, to 34,681 by 1996.

Finnie (2001) cautions, however, against jumping to the conclusion that the growing number of "temporary" Canadian workers in the United States greatly swells the true ranks of emigrants. He uses tax filer data to try to establish the number leaving permanently, giving lower and upper bounds that average out to numbers similar to those reflected in our Figure 2, which shows the number of Canadians obtaining permanent residence status according to U.S. immigration statistics. The rate of emigration has, however, clearly been rising, in part because of the conversion of temporary Canadian workers to permanent migrants. Thus the average number of permanent migrants according to U.S. immigration statistics rose from 16,654 in 1985-89 to 23,462 in $2000-2004$.

An important feature of this increased labour mobility between Canada and the United States is that it affected mostly highly qualified workers. Both countries assessed prospective immigrants in part on the basis of their education and domestic labour market requirements. It became even easier for Ph.D.'s in many fields, executives, and professionals of certain kinds to migrate. Further, the emigration opportunity spread to information technology experts and the like who did not necessarily have graduate degrees. But in contrast to the situation before 1965, blue collar and middle income workers could not share very much in this new, freer Canada U.S migration. ${ }^{9}$ They generally did not fit the criteria for "temporary" movement under the NAFTA rules, and their chances of getting a green card in the U.S. or landed immigrant status in Canada were very slim. This meant that the competitive pressures in terms of personal taxes became important at the top end, but were still absent for low and middle income Canadians. Consistent with this, in Figure 4 we see marginal tax rates for top income earners beginning to fall after 1995. This trend culminated in the federal budget of 2001 under which the threshold at which the highest rate of federal income tax (29\%) applied was raised from $\$ 60,009$ to $\$ 100,000$. The elimination of federal surtaxes on high earners was also completed in 2001.

Not only did the ease of movement, and the numbers moving, from Canada to the U.S. begin to rise after 1990, but public concern about the movement rose as well. By the mid 1990s the brain drain had become a political issue in Canada, and there were calls to reduce taxes in

\footnotetext{
${ }^{9}$ DeVoretz (1998) reports that the absolute number of unskilled migrants from Canada to the US approximately doubled in the early 1990s, but it remained at a very low level relative to the number of unskilled workers in Canada, as well as in comparison with the number of skilled migrants.
} 
order to stem it. (See Harris and Schmitt, 2005, for a recent contribution to the ensuing debates). There was also a concerted move to spend more on research both in universities and elsewhere in order to promote the "knowledge based economy" and, recently, programs to entice Canadian academics to remain in or return to Canadian universities. ${ }^{10}$

We are thus suggesting that, just as the disappearance of competitive discipline on the migration front may help to explain the expansion of government in Canada after 1965 along with changes in the structure of the tax system, the partial reimposition of that discipline after 1990 may be an important factor leading to observed income tax reductions along with reduced tax progressivity.

\section{A More Comprehensive View?}

The growth and financing of government is a complex issue, and is the result of forces of demand and supply filtered through political institutions. ${ }^{11}$ A more comprehensive view than we have presented so far would acknowledge additional facts and factors.

In the first place, as shown in Figure 5 where defense spending is omitted, public sector growth in Canada relative to that in the United States started in the 1950's. So we must be talking in this paper about the closing of the border as (just) one of the factors behind government growth.

[Figure 5 here]

The aspect of the history illustrated in Figure 5 that we have emphasized above - one that has not been explored extensively in Canada so far - concerns the supply side, namely a decline in the elasticity of labour supply because of the ending of migration to the U.S. the impact effect of which is to reduce the economic implications, and hence the full cost of, personal and especially of employment income taxation.

The elasticity of labour supply itself is a multi-faceted issue that is likely not driven only by the change in U.S. emigration law. Even if Canadians had been free to move to the U.S. in larger numbers they may not have done so in the late 1960's or early 1970's because of concerns about the Vietnam War, race riots, high crime rates, and poor public services. In other words, the elasticity of labour supply in Canada is likely a product of several economic and social developments in both countries.

Moreover, there may well be other supply side factors that also lead to higher levels of government spending. For example, entry of women into the labour force, an important phenomenon occurring all over the West throughout the period we are discussing, allows government to tax economic activity that previously could not be reached. Kau and Rubin (2002) argue that a great deal of the growth in the public sector in the United States since 1929 is attributable to the decline in the cost of raising revenue that resulted from the growing labour force participation of women. (Winer et al. 2008) have revised their estimates substantially

\footnotetext{
${ }^{10}$ Here we are referring, for example, to the Canada Research Chairs program.

${ }^{11}$ Tridimas and Winer (2005) provide a general discussion of the factors identified in the literature that lie behind the growth of government.
} 
downwards, but their story still stands to some extent.)

An additional supply side shock in the 1960's that deserves further consideration is the increased sensitivity of capital flows to taxation that followed liberalization of capital markets and further post-war declines in the cost of international transactions. It is interesting to analyze the effect of this shock using the model of a fiscal system introduced earlier. Figure 6 illustrates. Since the Laffer curve for capital income is now shifted in and turns backwards at a lower rate of tax (see panel B of the figure), the marginal political cost associated with this form of taxation increases: the same capital income tax revenue now requires a higher rate of taxation. In response to the now higher marginal political costs associated with this tax base, political parties are forced to reduce the emphasis on this form of taxation in favor of increased taxation of labour income. Thus it can be seen that the developments in capital markets in the 1960's and 1970's move the tax mix in the same direction as does the closing of the U.S border to Canadian emigration. As shown in Table 1, relative reliance on corporate taxation did indeed fall in the decade after 1960, from 4 to 3.4 per cent of GDP.

\section{[Figure 6 here]}

Note however that there is an essential difference between the shocks analyzed in Figures 3 and 6. A reduction in the cost of personal taxation that follows the closing of the border, as analyzed in Figure 3, leads to a larger equilibrium government size. In contrast, increasing the cost of capital income taxation, as in Figure 7, reduces equilibrium size as well as altering tax structure towards increased reliance on personal income taxation. So we can conclude that, while other supply side factors besides closing the border to emigration may have been involved in explaining the development of the Canadian fiscal system after 1965, there must be more to it than responses to an increase in the sensitivity of capital income to domestic taxation.

Of course there are demand factors at work too. It is not as if there were no earlier developments on the demand side in Canada, giving rise for example to the Unemployment Insurance Act in 1940 and the Family Allowance program in 1944, along with expansion of public education and other public services in response to the post-war baby boom, urbanization, and growing prosperity.

Finally, it should be noted that while it is necessary to look at the demand side to understand the evolution of the public sector, increases in demand alone are not sufficient to explain fiscal developments that include greater reliance on personal income taxation and reduced reliance on capital income taxation. The reader can verify that an upward shift in the marginal political benefit curve in Figures 3 or 6, as would follow any positive demand-side shock, leads to an equilibrium increase in reliance on all tax bases, a result Kenny and Winer (2006) refer to as a scale effect, and one they confirm for a large sample of countries. To replicate the stylized fiscal facts for Canada in the 1960s and 70s we need to contemplate the role of factors that result in changes in the relative political cost of financing public expenditure in different ways.

We do not deny that government growth and changes in fiscal structure after 1965 likely were the result of various factors, several of which have nothing to do with the Canada - U.S. migration regime. (See, for example, Ferris, Park and Winer, 2008) However, we suggest that 
the observations or correlations - (i) of more similarly sized public sectors in Canada and the U.S. while migration was essentially unrestrained before 1960; (ii) of the border closing with government growth in the 1960s and 70s along with changes in tax structure; (iii) and of the reopening of the border to highly trained professionals with reduced progressivity at the high end after 1990 - are as a whole suggestive of a role for migration.

The sense that migration and its relationship to fiscal structure in Canada is an under-studied topic is further strengthened if one recalls that in the mid 1960's the border did not just close in one direction. A few years before the U.S. imposed numerical limits on Canadian immigrants, Canada did the same thing to Americans through the immigration reform of 1962. Thus, we could establish one of the world's most generous welfare states without becoming a welfare magnet for low income Americans. If the border had been open for Americans to enter Canada in unlimited numbers, it is possible (no one knows for sure) that low income Americans would have relocated here for the sake of our free health care, and so on. (It is not irrelevant to note at this point that that many Americans did migrate here to avoid participation in the U.S. military during the war in Vietnam.) Substantial immigration of this type may have put pressure on Canadian governments to reduce spending. Thus, even if Canadians had not been interested in leaving the country to escape rising tax burdens, there certainly could have been fiscal discipline on their governments from labour mobility to Canada, rather than from it.

\section{The Broader Historical Migration Experience, and Canada's Migration Future}

\subsection{Canada before 1965}

In assessing the importance of what happened in 1968 as a result of the U.S. Immigration Act of 1965 , it is useful to set this event in a broader perspective. We do so briefly in this section.

The period of tight restrictions between 1968 and 1990 was a very unusual one for Canada - U.S. migration. Up to 1968 there were no quantitative restrictions. ${ }^{12}$ During the period from Confederation to 1900 there was a huge emigration from Canada to the U.S. A total of about nine hundred thousand people migrated according to U.S. immigration statistics ${ }^{13}$, taking French Canadian culture into New England, hockey into the major northern U.S. cities, and even the composer of "Oh Canada" into self-imposed exile. When one considers that the population of Canada in 1867 was close to 3.5 million, it is clear that this movement deserved the name it was given at the time, that is, "the Exodus".

In the early 1920's it was clear that the U.S. would clamp down on immigration and there were fears that Canadians would be affected. A total of 317,701 Canadians moved to the U.S. in 1923 and 1924 alone, in order to get in before the door closed. As things transpired, the Immigration Act of 1924, while shutting down immigration from the Old World, made a "hemispheric

\footnotetext{
${ }^{12}$ A visa requirement was instituted in the 1890s (Ramirez, 2001). Due to the great length of the border and the ease of informal cross-border movements, particularly in Western Canada, visa requirements were not always successfully enforced although enforcement became more stringent over time.

${ }^{13}$ Immigration statistics in both Canada and the US suffered from inconsistent definitions and practices in the $19^{\text {th }}$ century. It is not until about 1905 in both countries that the figures become reasonably reliable. Hence the figure for Canadian migration to the US between 1867 and 1918 is suggestive rather than precise.
} 
exemption" for the New World. Persons born in the Western Hemisphere would be admitted without numerical limit. While qualitative restrictions remained in force in order to allow the exclusion of groups deemed to be undesirable, these restrictions were not important for CanadaU.S. migration.

Over the 1920s as a whole, almost one million Canadians moved to the U.S. The importance of this population movement was recognized on both sides of the borders, as indicated, for example, by the publication of a major study on the Canadian born in the U.S. in the early 1940s (Truesdell, 1943).

While Canadian emigration to the U.S. was not significant in the 1930s or during the subsequent war years, it became important again in the post-war period. The late 1950s and early 1960s were difficult times for the Canadian economy. From 1955 to 1965, 490,962 Canadians left for the United States. No doubt the open border eased required adjustments to the time considerably. For example, when the Avro Arrow interceptor program was abruptly terminated by the Diefenbaker government in 1959, it has been reported that several thousand engineers released from the program moved to the U.S. After 1965, and before the free trade agreements, such a large and sudden migration across the border would have been impossible.

Economists showed significant interest in the implications of Canada-US migration. Dales (1966) developed a model of the Canadian labour force receiving injections of European labour at the same time that it bled Canadian-born emigrants to the south. Dales argued that the rate of departure to the United States was boosted by the enduring protectionist "National Policy" first implemented by John A. MacDonald's Conservative government in 1876. Tariff distortions made Canada a less desirable location for business than the U.S., and with free labour mobility there was an inevitable tendency for factors to relocate to the U.S., reducing the growth rate of the Canadian economy and retarding the country's development. Dales does not appear to have considered the possibility of a relationship between migration, and the size and structure of government.

Even from this quick historical overview, it is clear that the last 40 years or so have been very unusual ones in Canadian migration history. Prior to 1965, and over the previous 400 years of European presence in North America, there had never been any quantitative limit on the number of people who could move between Canada and what is now the United States. We have drawn attention to the fiscal aspects of this very distinct period in Canadian political economy. No doubt there are other dimensions to be explored as well. ${ }^{14}$

\subsection{Experience elsewhere: Europe versus Canada}

The history of migration to the U.S. from Europe shows both interesting parallels to, and contrasts with, Canada's experience. Historically, just like Canadians, European workers could relocate to the booming labour markets of the United States without quantitative restriction. But for Europeans this option was closed down more than 40 years earlier than for Canadians. Beginning in 1921 they became subject to quotas based on national origin, which took their final form in the Immigration Act of 1924. With labour mobility within Europe difficult, and other

\footnotetext{
${ }^{14}$ For further discussion of the issues, see Wildasin (2003, 2006).
} 
New World destinations less attractive than the U.S., the quotas imposed in the 1920s greatly reduced labour mobility for European workers. The elasticity of labour supply in Europe likely fell considerably as a result and the marginal political cost of taxing labour and other personal income likely also decreased. On the basis of our model, increased rates of personal taxation and an expansion of government would have been predicted in Europe after 1924, just as they are predicted for Canada after 1965 by our model. Checking this hypothesis is quite difficult however, and is certainly beyond the scope of this paper. Fiscal history in the 1920's is heavily colored by the aftermath of the First World War, while the Great Depression and rearmament shapes European fiscal systems in the 1930's. ${ }^{15}$

Another parallel between European and Canadian experience is that in recent years labour mobility has increased. In Europe mobility has risen through (i) reduced barriers within the EU, (ii) expansion of the EU, and (iii) immigration from lower income countries. Increased intra-EU mobility likely has had similar effects to the increased Canada-U.S. mobility seen since 1990: a higher marginal political cost of personal taxation, resulting in lower personal taxes and some shrinkage of government. Substantial movement in the latter direction after 1990 has been seen in the U.K., Ireland, the Nordic countries, the Netherlands, Portugal and Spain. Germany, France, and Italy have resisted the trend, but with the election of the Merkel and Sarkozy governments in Germany and France in 2006 and 2007 respectively, there is, perhaps, a regime change in the predicted direction in the offing even there.

There are also interesting differences between the European and North American experience. For example, while North America has had high capital mobility throughout the postwar period, capital mobility started from a low level and increased greatly in Europe over the same period. This may be why decreases in capital taxes in Europe have been marked, while they have been less important in Canada and the U.S. Another important difference is that while the North American economy has one dominant partner, the U.S., in Europe that is not the case. One may perhaps think of the European analogue to the U.S. as the four large core countries - Germany, France, Italy and the UK. There are significant language and other barriers to mobility among these countries, and between them and other high income "old EU" countries that likely dampen labour supply elasticity not only in the core but in the old fringe as well. The significant increase in mobility has come about through expansion of the EU to many lower-income countries, first in the Mediterranean area, and then in the East. This produces conditions similar to those faced by the US before 1921, and may have effects in our model quite distinct from those we have analyzed above. For example, the prospect of a large influx of immigrants putting a strain on public services may reduce the marginal political benefit from government spending, so that a decrease in the size of government, and at least in its composition, may be demanded by voters in the receiving countries, a result quite different than the supply-side driven increase in public expenditure that may have occurred in Canada after 1965.

\subsection{Canada-U.S. migration future}

Before we conclude this effort to draw attention to an unexplored and potentially important episode in Canadian economic and social history, we use our analysis as a background against which to briefly speculate about the likely future of Canada - U.S migration arrangements.

\footnotetext{
${ }^{15}$ See Aidt and Jensen (2008) for further discussion of European fiscal systems over this period.
} 
Predicting the impacts of increased labour mobility between Canada and the U.S. is a difficult task, one that deserves study in a separate paper. However, we will tentatively make three observations. One is that the Exodus conditions (referred to earlier) of the late 19th century and 1920's were aggravated by the highly protectionist Canadian trade regime of the time. With the larger volume of trade relative to the economy as a whole occurring under NAFTA, this problem has now been removed. To a reasonable approximation Canada is as good a location as the U.S. for industry. Thus there seems to be little risk of a wholesale relocation of population and industry to the south, as happened in the late 19th and early 20th centuries, if the border should become much more open to emigration to the United States.

A second observation is that, as many have observed (e.g., Mueller 1998), if Canadians want a higher level of public services, and get "good value" for their tax dollars, Canada can be higher than that faced by Americans without precipitating exit even under completely free migration.

Our final observation is that completely free labour mobility would allow low income Americans to move to Canada, and if this prospect came to pass, it could result in electoral pressure on Canadian governments to reduce social benefits and increase taxes at the lower end of the income distribution even if, on average, tax burdens and public services remained relatively high. In other words, low income migration northward could lead to pressure to reduce the redistributive aspect of the Canadian public sector.

For this reason, and because highly trained people can already move under existing arrangements to some extent, in our view it is likely that any further migration liberalization will take the form of easing the movement of highly qualified workers further. This produces even greater "brain drain" pressure on Canadian governments which can be accommodated by reducing personal income taxes at the top end, and by making various public spending and regulatory adjustments that would be valued by highly qualified workers. Such adjustments could, for example, include even higher spending on post secondary education and research, as well as allowing "two tier" health care.

Since these adjustments can, in principle, be made without scaling back the redistributive social programs that are part of the existing political equilibrium, it seems a reasonable guess that opening the border wider to the highly qualified, but not to lower income groups, would be less disruptive politically and socially. We suspect that this is the route that will be favoured by Canadian politicians and negotiators. Because of the wider implications should low wage migration be made easier, our guess is that the U.S. will not oppose this approach. We therefore suggest that it will be the one adopted in any further liberalization of Canada - U.S. labour mobility.

\section{Concluding Remarks}

Using a model of equilibrium fiscal policy as a guide to our discussion, we have argued that a first look at the facts suggests that the near closing of the U.S. border to Canadian emigrants under the U.S. Immigration Act of 1965 most likely had an effect on tax structure in the following two decades, causing increased reliance on personal income taxation in the tax mix 
and higher marginal income tax rates. We have also suggested that the closing of the border may have contributed to growth of government in Canada, and to differences in the evolution of income inequality in Canada vis a vis the United States. A preliminary regression analysis supports the conjecture about the effect of the closing of the border on government size.

This closing of the border can be set in a broader migration context, both with respect to the history of Canada and with respect to emigration from and within Europe. It is clear that what happened in 1965 caused an important break with the past for Canadians, just as did the U.S. Immigration Act of 1924 for Europeans. Prior to 1965 there had never been quantitative limits on the emigration of Canadians to the U.S. This allowed large movements to occur during periods of higher growth in the U.S. than Canada (Lines, 1978; Ramirez, 2001). With the increased mobility allowed under the Canada-U.S. free trade agreement and NAFTA, we have now returned to somewhat more normal conditions. The ending of unlimited emigration from Europe to the U.S. in 1924 presents a parallel to the closing of the Canada-U.S. border in the late 1960s. This change could, in principle, have contributed to the growth of welfare states in Europe and changes in tax levels and structure similar to those we have analyzed. (These might be difficult or impossible to establish empirically, of course, given the confounding influences of fascism, depression and war.) The greater ease of intra-European migration in an expanding EU during the postwar period, may have had effects that can also be analyzed with the help of the approach outlined here.

The increased cross-border mobility that has been seen in the period of the free trade agreements, particularly for highly qualified workers, would have been predicted by our model to lead to a shift in tax mix away from labour income and to a reduced size of government. The 1990s saw great concern in Canada about brain drain and strenuous efforts on the part of governments to reduce spending and eliminate deficits - - with a direct effect on the size of government and allowing the gradual reduction of personal income tax rates that began a little later. Since the mid 1990s there has been a large reduction in the bulge in the size of government in Canada vs. the U.S. that was seen in the 1970 s and 80 s. These trends are again consistent with the predictions of our model. However, we have also recognized that the size and structure of government is a complex phenomenon, and that emigration to the United States is just one of several important factors to consider.

Our primary purpose in this paper has been to point to an important event in Canadian economic and social history that has not been given the attention we think it warrants. The ending of the hemispheric exemption for Canadians in the mid 1960's reduced emigration to the U.S. dramatically in the following two decades. It would not be surprising to find, on further study, that a shock of this kind had far-reaching impacts on several dimensions of Canadian public policy. It is to be hoped that students of Canadian fiscal history will devote serious attention to those aspects in future research, as well as to the consequences for the public sector of the substantial out migrations of the 19 th and early 20 th centuries. 


\section{References}

Aidt, Toke and Peter S. Jensen (2008). "Tax Structure, Size of Government, and the Extension of the Voting Franchise in Western Europe, 1860-1938”. Working Paper, Cambridge University.

Card, David (2003). "Canadian Emigration to the United States", in Beach, Charles M., Alan G. Green and Jeffrey G. Reitz (eds.), Canadian Immigration Policy for the $21^{\text {st }}$ Century, John Deutsch Institute, Queen's University in cooperation with McGill-Queen's University Press, Montreal and Kingston, 295-314.

Carter, Susan B., Scott Sigmund Gartner, Michael R. Haines, Alan L. Olmstead, Richard Sutch, and Gavin Wright (2006), Historical Statistics of the United States, Earliest Times to the Present, Millennial Edition, Vol. 1, Cambridge University Press, New York.

Dales, John H. (1966). The Protective Tariff in Canada's Development: Eight Essays on Trade and Tariffs When Factors Move With Special Reference to Canadian Protectionism, 1870-1955. University of Toronto Press, Toronto.

Davies, James B. and Junsen Zhang (1996). "Measuring Marginal Income Tax Rates for Individuals in Canada: Averages and Distributions Over Time". Canadian Journal of Economics 29, 959-75.

DeVoretz, Don (1998). “Canadian Human Capital Transfers: The USA and Beyond”, C.D.Howe Institute Commentary No. 115, October.

Ferris, J. Stephen, SooBin Park and Stanley L. Winer (2008). "Studying the Role of Political Competition in the Evolution of Government Size Over Long Periods." Public Choice, forthcoming. At www.carleton.ca/ $\sim$ winers.

Finnie, Ross (2001). "The Brain Drain: Myth and Reality, What It Is and What Should be Done”, Choices IRPP, Vol. 7, No. 6, November: 3-29.

Firestone, O. J. Canada's Economic Development: 1867 - 1953, Bowes and Bowes; London, 1958.

Gillespie, W. I. (1991) Tax, Borrow and Spend: Financing Federal Spending in Canada, 18671990. Carleton Library Series, no. 170. Ottawa: Carleton University Press.

Green, Alan G. (1994). "A Comparison of Canadian and US Immigration Policy in the Twentieth Century", in DeVoretz, Don (ed.), Diminishing Returns, The Economics of Canada's Recent Immigration Policy. C.D. Howe Institute, Toronto, 31-64.

Hamilton, J. D. (1994). Time Series Analysis. Princeton University Press. 
Harris, Richard G, and Nicolas Schmitt (2005). "Labour Mobility and a North American Common Market: Implications for Canada". In S.T. Easton, R. G. Harris and N. Schmitt. Brains on the Move: Essays on Human Capital Mobility in a Globalizing World and Implications for the Canadian Economy. Policy Study 42, Toronto: C.D. Howe Institute, 133-174.

Hettich and Winer (1999). Democratic Choice and Taxation: A Theoretical and Empirical Analysis. Cambridge University Press

Kenny, Lawrence and Stanley L. Winer (2006). "Tax Systems in the World: An Empirical Investigation into the Importance of Tax Bases, Collection Costs, and Political Regime". International Tax and Public Finance 13(2/3), 181-215.

Leacy, F. H. ed. (1983). Historical Statistics of Canada. Macmillan Company

Lines, Kenneth (1978). British and Canadian Immigration to the United States Since 1920. R\&E Associates, San Francisco.

Love, Roger and Michael C. Wolfson (1976). Income Inequality: Statistical Methodology and Canadian Illustrations, Statistics Canada, Catalogue No. 13-559 Occasional, March.

MacKinnon, J. G. (1996). "Numerical Distribution Functions for Unit Root and Cointegration Tests". Journal of Applied Econometrics 11(6), 601-618.

Mueller, Dennis (1998) . "Constitutional Constraints on Governments in a Global Economy." Constitutional Political Economy 9, 171-186.

Murphy, Kevin M., W. Craig Riddell, and Paul M. Romer (1998), "Wages, Skills, and Technology in the United States and Canada", in Elhanan Helpman (ed.), General Purpose Technologies and Economic Growth, MIT Press, Cambridge Mass: 283-309.

Ramirez, Bruno (2001), Crossing the $49^{\text {th }}$ Parallel, Migration from Canada to the United States, 1900 - 1930, Cornell University Press, Ithaca and London.

Saez, Emmanuel and Michael R. Veall (2005). "The Evolution of High Incomes in Northern America: Lessons from Canadian Experience", American Economic Review 95(3), 831-849.

Saikkonen, P. (1991). "Asymptotically Efficient Estimation of Cointegration Regressions", Econometric Theory 7(1), 1-21.

Statistics Canada (2002), Income in Canada 2000, Catalogue No. 75-202-XIE, November.

Statistical Abstract of the United States, various editions (1998-2005).

Tomasi, Silvano M. and Charles B. Keely (1975), Whom have we welcomed?: The adequacy and quality of United States immigration data for policy analysis and evaluation, Center for Migration Studies, Staten Island NY. 
Tridimas, George and Stanley L. Winer (2005). "The Political Economy of Government Size". European Journal of Political Economy 21, 643-666.

Truesdell, Leon E. (1943). The Canadian Born in the United States; An Analysis of the Statistics of the Canadian Element in the Population of the United States, 1850 to 1930. Yale University Press, New Haven.

Urquhart, M.C., Canadian Historical Statistics and Gross National Product, 1870-1926, McGillQueen's University Press

Vemaeten, Arndt, W. Irwin Gillespie and Frank Vermaeten (1995). "Who Paid the Taxes in Canada, 1951-1988?” Canadian Public Policy

Winer, Stanley L. and J. Stephen Ferris (2008). "Searching for Keynesianism." European Journal of Political Economy 24, 294 - 316.

Winer, Stanley L. , Michael Tofias, Bernard Grofman and John Aldrich (2008). "Trending Economic Factors and the Structure of Congress in the Growth of Government. Public Choice, 113, 389-402

Wildasin, David (2003). 'Fiscal Policy, Human Capital and Canada-U.S Labour Market Integration. Unpublished, University of Kentucky, September.

Wildasin, David E. (2006). "Global Competition for Mobile Resources: Implications for Equity, Efficiency and Political Economy". CESifo Economic Studies 52(1). 61-110. 


\begin{abstract}
Appendix
Preliminary (Cointegrating) Regressions for Non-interest Federal Government Spending Relative to GNP, 1900 - 2000, Focusing on the Role of Emigration to the United States.
\end{abstract}

In this Appendix we present a preliminary model of the longer run, or trend in, the size of the federal government's non-interest spending relative to GNP, based on Ferris Park and Winer (2007) and Winer and Ferris (2008). Since some data for emigration to the U.S. is missing before 1900, we start with that year and consider a period covering the 20th century. Our purpose here is to consider whether or not reduced emigration to the United States from Canada between 1900 and 2000 is associated statistically, and importantly, with increased public expenditure in Canada over longer periods of time, after controlling for a set of factors commonly used in studies of government size. We note that emigration to the United States is not a factor considered by the studies cited above.

Our discussion will be brief, omitting references to the literature and, for the most part, omitting a discussion of expected signs of coefficients which can be found in the papers just referred to.

We consider federal non-interest expenditure because it has been consistently measured by Gillespie from 1867 (1991, updated by Ferris and Winer, 2008). This measure relies on adjusted public accounts data, and is approximately the same as the national income accounts measure of government spending after 1929 which is used in constructing Figures 1 and 5.

The history of emigration based on U.S. immigration statistics over the period $1900-2000$ is shown on Figure A1, along with federal non-interest spending relative to GNP since 1870 in Figure A2. The non-shaded parts of the figures represent the sample considered in the statistical work. The' exodus' referred to in the text in the 19th century is clearly evident in the data in Figure A1, as is a large but somewhat smaller (relative to population) outmigration in the 1920's. The emigration that peaked in the mid-1960's is clearly evident, as is the fact that this more recent episode of out-migration was not of the same order of magnitude as those of the 19th and early 20 th centuries.

[Figures A1 and A2 here] 
Figure A1

Permanent Emigration to the U.S. as a Percent of Population Canada, $1870-2000$

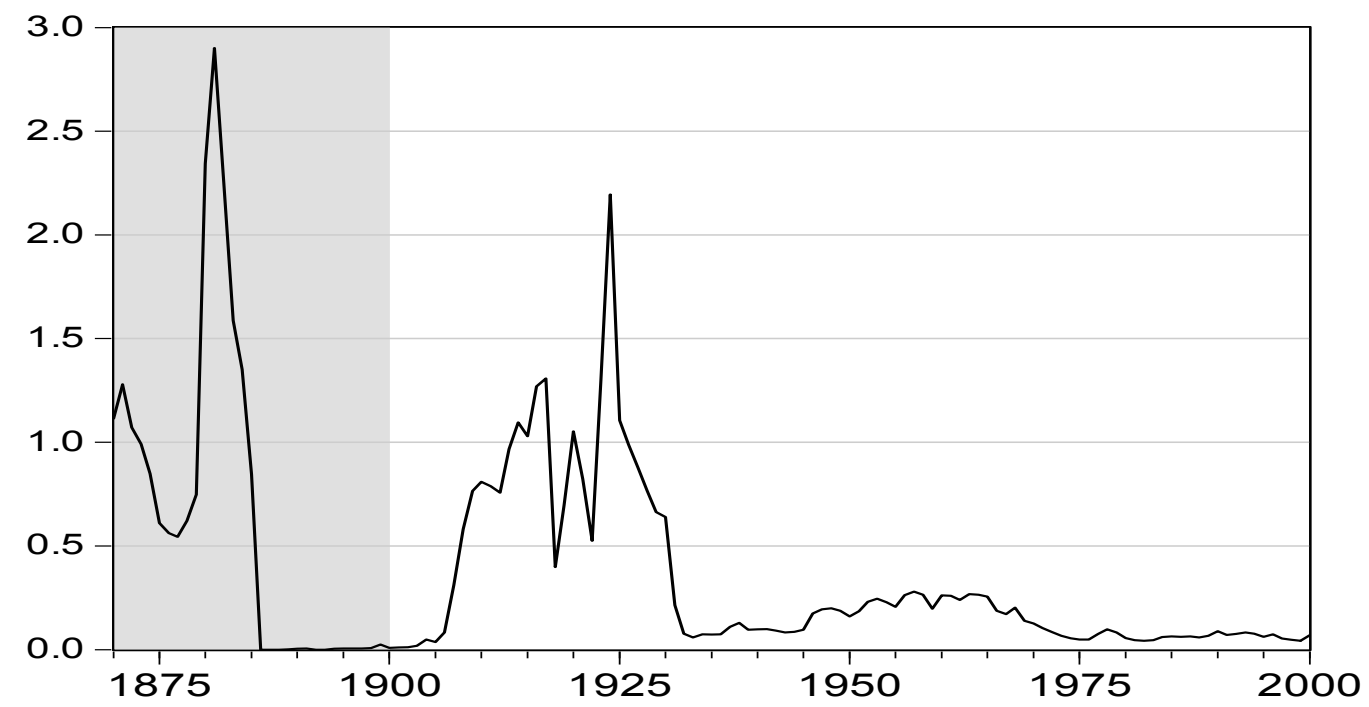

Note to Figure A1: Missing data for 1886-88 and 1892-93 set equal to zero.

Figure A2

Federal Government Non-interest Spending Relative to GNP Canada $1870-2000$

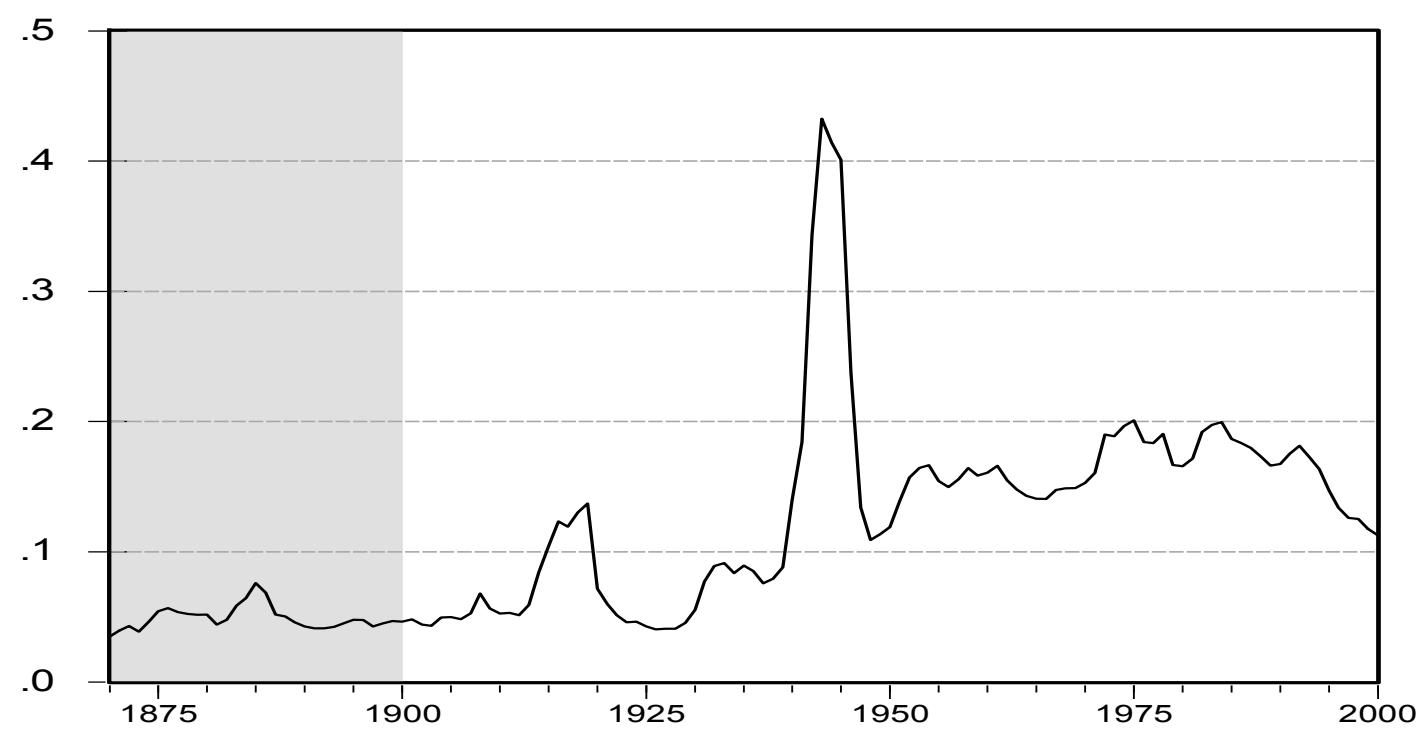


Turning then to the specification of a long run model of government spending, we begin with the usual economic factors: real income per capita (REAL INCOME), a measure of the urban/rural composition of the economy - here represented by the proportion of the labour force in agriculture (AGRICULTURE) - and a demographic variable, the percent of population less than 17 years in age (\%YOUNG). Population size often appears as a test of the 'publicness' of government services. But we do not include this variable here as it is very highly correlated with real income per capita (at about 0.98 for $1900-2000$ ). The sources for these and other data are given below.

For a country like Canada where immigration flows have been substantial, the immigration to population ratio (IMMIGRATION) is another demographic characteristic that may shape long run government size, especially in the period before the First World War. This variable in principle includes some immigration from the U.S. To begin with, we shall add emigration to the U.S. relative to Canadian Population (EMIGRATION_US) to our model. We expect a negative sign for this variable - less emigration to the U.S should be associated with increases in government size in Canada.

As an alternative to EMIGRATION_US, we also employ indicator variables reflecting different Canada - U.S. emigration regimes. These are the effective restriction following the U.S. legislation of 1965, which came into force in 1968 (EMIGRATION_1968_1990), and the introduction of the FTA in 1990, effective in 1991 and continuing later under the NAFTA (EMIGRATION_FTA). These regime indicators are likely to be exogenous to federal government size, while EMIGRATION_US may also reflect factors, such as recessions, that simultaneously impact both migration and government spending. We expect the emigration regime of 1968 to 1990 to result in larger government, and that following the Free Trade Agreement to be associated with reduced government size.

Another factor that has come into prominence in studies of government size is the degree to which an economy is exposed to foreign shocks, measured here by the sum of exports and imports relative to GDP (OPENNESS). Openness in this sense is included here as a measure of the exposure of the economy to external shocks. In the 19th century, it may also serve as a proxy for the tax base of the tariff. We include a dummy variable indicating when the exchange rate was fixed (FIXED EXCHANGE), to reflect the importance of balance of payments constraints on domestic policy choices. It will be interesting to see how the results for the emigration variables compare to those for openness and the exchange regime, because both sets of factors represent external conditions underlying domestic policy considerations.

Finally, we include a set of dummy variables to incorporate the influence of several substantial external shocks in our time period: World War One (WWI); World War Two (WWII); and a Peacock-Wiseman type displacement effect after WWII often included in models of government size (WWIIaftermath = 1 from 1947 on). We also experimented with inclusion of a shift dummy representing the long run effect of the OPEC oil shock of the mid 1970's (OILSHOCK SHIFT = 1 from 1974 on). However, the latter factor does not substantially alter the regression results, and equations using this shift are omitted in what follows.

The regression results are presented in Table A1. (The results for the 1945-2000 period remain almost the same if the period $1947-2000$ is used instead.) Here all variables except the dummies are used in log form, and the reported $t$ statistics are robust with respect to heteroscedasticity and autocorrelation unless otherwise stated. 
[Table A1 here]

As can be seen from the Adjusted Dickey-Fuller and Phillips - Perron statistics, the regressions can be considered cointegrating regressions that represent the longer run trend in federal government size. Robust standard errors are reported. Columns (3), (5) and (6) present results adjusted using the Saikkonen method (1991), which allows for possible serial correlation between (potentially endogenous) regressors. Here leads, lags and the current value of the change in all regressors except for the dummy variables are added to the original equation. Two leads and lags are used, and only the coefficients on contemporaneous variables are shown. The $t$ statistics of these equations are then adjusted by the ratio of the original standard error to a 'long run' standard error. The latter is estimated using a vector auto regression (with 3 lags) for the error in the Saikkonen regression (see Hamilton 1994, chapter 19 for details.)

Before turning to the role of emigration to the United States, we briefly review the results concerning other variables, taking the table of results as a whole. It can be seen in Table A1 that the coefficient on income is positive, small and insignificant (except in columns 3 and 5 where the Saikkonen adjustment is applied). The proportion of the labor force in agriculture has a positive effect on government size, which also tends to be insignificant, while the percent of the population that is young is unstable and switches sign across the samples and equations.

The wars have their usually expected effects.

The role of openness of the economy and the exchange regime are consistently negative and significant: more openness and a fixed exchange rate tend to reduce federal government size, perhaps by enhancing constraints on domestic policy choices. These results foreshadow those for emigration.

We then come to the role of migration, the focus of this study. Immigration from all countries (relative to the population) appears to reduce the size of government somewhat, at least in the period before the Second World War. In the equations for 1921 and on, this variable is not significant.

Of key interest is the fact that emigration to the United States (EMIGRATION_US) has a negative and significant effect in all equations. Thus less emigration to the U.S. is associated with a smaller federal public sector. Moreover, the emigration regime indicator EMIGRATION_1968_1990 has a positive and significant sign for 1945 on (see column 4a), and a positive sign in the equation for 1921 on (column 2a), indicating that after the 1965 change in U.S. emigration law became effective and until the free trade agreement, the federal public sector was smaller than it otherwise would have been. These effects are confirmed by the Saikkonen equations in columns (3), (5) and (6).

The indicator of a relaxed emigration regime after the free trade agreements in 1990 and 1993 is positive and insignificant in the least squares results in columns (2a) and (4a). In the Saikkonen equation in column (6) it is also significant. This last result is unexpected.

To assess the quantitative importance of key results, Figure A3 compares the prediction for government size using the regression equation in column (4a) that employs the emigration regime indicator EMIGRATION_1968_1990, with predicted government size based on this equation when the emigration restriction is removed. It can be seen that the federal government's non-interest predicted spending is lower without the restriction, and it turns out that this is so by about 2 percentage points (16.3\% versus $14.4 \%$ ) on average over the $1965-75$ period. 
[Figure A3 here]

If one uses the elasticity form of the effect of emigration in column (4), of -0.13 , the $80 \%$ fall in emigration (relative to population) that occurred between 1965 and 1975 has the effect of reducing federal government size relative to GNP by about $10 \%$.

We interpret these results as suggesting that reduced emigration to the United States in the 1968 to 1990 period appears to be associated both statistically and substantively with larger government spending in Canada, and that further study of the role of international migration in Canadian public finance is warranted. 


\section{Variables and Data Sources/. Based on Winer and Ferris (2008) at www.carleton.ca/ winers.}

AGRICULTURE = proportion of the labour force in agriculture.

1871-1926: Urquhart, (1993), 24-55; 1926-1995 Cansim series D31251 divided by D31252; 1996-2001: Cansim II series V2710106 divided by V2710104.

EXPORTS and IMPORTS $=$ exports and imports, millions.

1870-1926, Urquhart, (1993) Table 1.4; 1927-1960, Leacy et al, (1983), Series G383, 384; 1961-2001: CANSIM series D14833 \& D14836.

EMIGRATION_US_NUMBER = numbers of permanent migrants from Canada (country of last origin) to the United States

Carter et al. (2006) Table Ad163 for 1946-1997 and Statistical Abstract of the United States, various editions, for 1998-2005.

EMIGRATION_US = emigration to the United States from Canada as a percent of Canadian population. Calculated as: EMIGRATION_US_NUMBER / (POP*1000), in percent.

EMIGRATION_1968_1990=1 for $1968-1990 ;=0$ otherwise.

EMIGRATION_FTA $=1$ from 1991 on; $=0$ otherwise.

The FTA became effective in 1991. The NAFTA was effective in 1994.

FEDERAL EXPENDITURE = total federal government expenditure net of interest payments, in millions. 1870-1989: Gillespie (1991), pp.284-286; 1990-1996: Public Accounts of Canada 1996-97: 1997-2000: Federal Government Public Accounts, Table 3 Budgetary Revenues Department of Finance web site, September 2001. Updated by Ferris and Winer (2008). To this we add the return on government investment (ROI) originally subtracted by Gillespie for his own purposes. Expenditure is net of interest paid to the private sector. Data on ROI: 1870 to 1915: Public Accounts 1917 p.64; 1915-1967: Dominion Government Revenue and Expenditure: Details of Adjustments 1915-1967 Table W-1; 1916-17 to 1966-67: Securing Economic Renewal - The Fiscal Plan, Feb 10, 1988, Table XI; 1987-88 to 1996-97: Public Accounts 1996, Table 2.2. Interest on the Debt (ID) was subtracted out (with adjustment for interest paid to the Bank of Canada (BCI) ultimately returned to the government). Data on ID: 1870-1926: Historical Statistics of Canada, Series H19-34: Federal Government budgetary expenditures, classified by function, 1867-1975; 1926-1995: Cansim D11166. 1996-2000: Cansim D18445. Finally, data for BCI: copied by hand from the Annual Reports of The Bank of Canada, Statement of Income and Expense, Annually, $1935-2000$. Net Income paid to the Receiver General (for the Consolidated Revenue Acct). Note: all government data are converted from fiscal to calendar years, and allows for a change in the definition of the fiscal year in 1906/07, as described in Gillespie (1991, Appendix C).

FEDERAL SIZE = non-interest federal government expenditure relative to GNP. Calculated as: (FEDERAL EXPENDITURE) / (GNP).

FIXED EXCHANGE $=1$ if exchange rate fixed; $=0$ otherwise.

Periods when exchange rates were fixed (or 'heavily' managed) in Canada are: 1870-1914, 1926-1931, 1939-1951, and 1960-1972.

GNP = gross national product, in millions of current dollars.

1870-1926: Urquhart (1993), pp. 24-25 (in millions); 1927-1938: Leacy et al (1983), Series E12, p.130; 1939-1960

Canadian Economic Observer, Historical Statistical Supplement 1986, Statistics Canada Catalogue 11-210 Table

1.4. CANSIM D11073 = GNP at market prices. 1961-2001 Cansim I D16466 = Cansim II V499724 (aggregated from quarterly data).

IMMIGRATION_NUMBER = immigration to Canada from all countries, thousands. 
1868 - 1953: Firestone (1958), Table 83, Population, Families, Births, Deaths; Updated by Cansim D27 (1955 to 1996). Cansim Sum of X100615 (Females) plus X100614 (Men) for 1954;1997-2001, Cansim D27 (sum of quarters).

IMMIGRATION= immigration relative to Canadian population.

Calculated as: IMMIGRATION_NUMBER/POP.

$\mathbf{L n}=$ the $\log$ operator.

OILSHOCK SHIFT $=1$ for 1974 onward; $=0$ otherwise.

OPENNESS $=$ openness of the economy to trade.

Calculated as: (EXPORTS + IMPORTS) / GNP.

$P=$ GNP deflator before 1927 and GDP deflator after $(1986=100)$.

1870-1926: Urquhart, (1993), 24-25;1927-1995 (1986=100): Cansim data label D14476; 1996-2001 Cansim

D140668. All indexes converted to $1986=100$ basis.

POP $=$ Canadian population, thousands.

1870-1926: Urquhart, (1993), 24-25; 1927 - 1995: CANSIM data label D31248; 1995 - 2001: Cansim D1 (average of four quarters).

REAL INCOME $=$ real income per capita.

Calculated as: $(\mathrm{GNP} * 1000) /((\mathrm{P} / 100) * \mathrm{POP})$.

WWI $=1$ for $1914-1919 ;=0$ otherwise.

WWII $=1 / 2$ in 1940,1 for $1941-1945,1 / 2$ in $1946 ;=0$ otherwise.

WWIIAftermath $=1$ from 1946 onward; $=0$ otherwise.

The WW1 and WW2 dummies apply to spending relative to GNP, and take into account the actual result of mobilization and demobilization as revealed by LnGSIZE in each of the world wars.

\%YOUNG = percentage of the population below 17.

1870-1920 Leacy et al (1983). Interpolated from Census figures Table A28- 45 sum of columns 29, 30, 31, and 32 all divided by 28 (adjusted to make 1921 the same); 1921-2001 Cansim C892547. 
Table A1: A Preliminary Model of Federal Government Non-interest Expenditure

Relative to GNP (FEDERAL SIZE), 1900 - 2000

OLS estimation (Absolute value of Newey-West HAC standard errors, unless otherwise stated)

\begin{tabular}{|c|c|c|c|c|c|c|c|c|}
\hline $\begin{array}{c}\text { Explanatory Variables } \\
\text { (in log form, except for: WWI, } \\
\text { WWII, WWII - } \\
\text { AFTERMATH, FIXED } \\
\text { EXCHANGE) }\end{array}$ & $\begin{array}{l}1900-2000 \\
\text { (1) }\end{array}$ & $\begin{array}{l}1921-2000 \\
\text { (2) }\end{array}$ & $\begin{array}{c}1921-2000 \\
\text { Using emigration } \\
\text { regimes } \\
\text { indicators } \\
\text { (2a) }\end{array}$ & $\begin{array}{l}1921-2000 \\
\text { Saikkonen t's } \\
\text { for col(2) } \\
\text { (3) }\end{array}$ & $1945-2000$ & $\begin{array}{c}1945-2000 \\
\text { Using emigration } \\
\text { regimes } \\
\text { indicators } \\
\\
(4 a) \\
\end{array}$ & $\begin{array}{c}1945-2000 \\
\text { Saikkonen t's } \\
\text { for col (4) } \\
\text { (5) }\end{array}$ & $\begin{array}{c}1945-2000 \\
\text { Emigration regimes } \\
\text { Saikkonen t's (a) } \\
\text { for col (4a) } \\
(6)\end{array}$ \\
\hline REAL INCOME & $\begin{array}{c}0.37 \\
(0.70)\end{array}$ & $\begin{array}{c}0.35 \\
(0.71) \\
\end{array}$ & $\begin{array}{c}0.14 \\
(0.32)\end{array}$ & $\begin{array}{l}0.96 * * \\
(2.50)\end{array}$ & $\begin{array}{c}0.40 \\
(0.66)\end{array}$ & $\begin{array}{c}-.02 \\
(0.04) \\
\end{array}$ & $\begin{array}{l}3.54 * \\
(4.31) \\
\end{array}$ & $\begin{array}{l}-\mathbf{- 0 . 2 5} \\
(0.74)\end{array}$ \\
\hline AGRICULTURE & $\begin{array}{c}0.09 \\
(0.03)\end{array}$ & $\begin{array}{c}0.14 \\
(0.51)\end{array}$ & $\begin{array}{c}0.02 \\
(0.23)\end{array}$ & $\begin{array}{c}0.16 \\
(0.75)\end{array}$ & $\begin{array}{c}0.13 \\
(0.44)\end{array}$ & $\begin{array}{c}-.04 \\
(0.16)\end{array}$ & $\begin{array}{l}1.71 * \\
(4.20)\end{array}$ & $\begin{array}{l}-0.09 \\
(0.56)\end{array}$ \\
\hline \%YOUNG & $\begin{array}{l}-0.12 \\
(0.31)\end{array}$ & $\begin{array}{c}0.73 \\
(0.23)\end{array}$ & $\begin{array}{c}-0.28 \\
(-0.90)\end{array}$ & $\begin{array}{l}1.94 * \\
(5.03)\end{array}$ & $\begin{array}{l}-0.27 \\
(0.95)\end{array}$ & $\begin{array}{l}-0.45 \\
(1.47)\end{array}$ & $\begin{array}{l}0.50 * * \\
(2.03)\end{array}$ & -0.72 \\
\hline OPENNESS & $\begin{array}{c}-0.614 * \\
(2.77)\end{array}$ & $\begin{array}{l}-0.69^{*} \\
(4.42)\end{array}$ & $\begin{array}{l}-0.66^{*} \\
(3.46)\end{array}$ & $\begin{array}{c}-0.36 * * * \\
(1.97)\end{array}$ & $\begin{array}{l}-0.91 * \\
(4.93)\end{array}$ & $\begin{array}{l}-0.77^{*} \\
(-4.96)\end{array}$ & $\begin{array}{l}-1.54 * \\
(11.87)\end{array}$ & $\begin{array}{l}-1.02^{*} \\
(12.25)\end{array}$ \\
\hline FIXED EXCHANGE & $\begin{array}{c}-0.18 * \\
(4.05)\end{array}$ & $\begin{array}{l}-0.15 * \\
(5.45)\end{array}$ & $\begin{array}{l}-0.14 * \\
(3.56)\end{array}$ & $\begin{array}{c}-0.06 * * * \\
(1.97)\end{array}$ & $\begin{array}{l}-0.13 * \\
(4.76)\end{array}$ & $\begin{array}{l}-0.14 * \\
(5.11)\end{array}$ & $\begin{array}{l}-0.07 * \\
(5.45)\end{array}$ & $\begin{array}{l}-0.16 * \\
(21.56)\end{array}$ \\
\hline WWI & $\begin{array}{l}0.75^{*} \\
(5.15)\end{array}$ & & & & & & & \\
\hline WWII & $\begin{array}{l}1.52 * \\
(5.52)\end{array}$ & $\begin{array}{l}1.49 * \\
(5.75)\end{array}$ & $\begin{array}{l}1.52 * \\
(5.43)\end{array}$ & $\begin{array}{l}1.14 * \\
(9.66)\end{array}$ & $\begin{array}{c}1.33 * \\
(13.09)\end{array}$ & $\begin{array}{c}1.35 * \\
(13.57) \\
\end{array}$ & $\begin{array}{l}1.85 * \\
(18.8)\end{array}$ & $\begin{array}{l}1.41 * \\
(19.42)\end{array}$ \\
\hline WWII-AFTERMATH & $\begin{array}{l}0.70^{*} \\
(4.43)\end{array}$ & $\begin{array}{l}0.69 * \\
(5.42) \\
\end{array}$ & $\begin{array}{l}0.86^{*} \\
(6.53)\end{array}$ & $\begin{array}{c}0.06 \\
(0.45) \\
\end{array}$ & $\begin{array}{l}0.18 * \\
(3.26)\end{array}$ & $\begin{array}{c}0.10 * * * * \\
(1.74)\end{array}$ & $\begin{array}{l}0.71 * \\
(8.43)\end{array}$ & $\begin{array}{l}0.33 * \\
(5.64) \\
\end{array}$ \\
\hline IMMIGRATION & $\begin{array}{l}-0.12 * \\
(3.80)\end{array}$ & $\begin{array}{c}-0.06 * * \\
(2.11) \\
\end{array}$ & $\begin{array}{l}-0.20 * \\
(5.70)\end{array}$ & $\begin{array}{c}0.03 \\
(0.61)\end{array}$ & $\begin{array}{l}-0.01 \\
(0.22)\end{array}$ & $\begin{array}{l}-0.16 \\
(0.33) \\
\end{array}$ & $\begin{array}{l}-\mathbf{- 0 . 0 2} \\
(0.98)\end{array}$ & $\begin{array}{c}-0.05^{* * *} \\
(2.35)\end{array}$ \\
\hline EMIGRATION_US & $\begin{array}{l}--0.02 \\
(0.63) \\
\end{array}$ & $\begin{array}{l}-0.18^{*} \\
(5.22)\end{array}$ & & $\begin{array}{l}-0.41^{*} \\
(6.54)\end{array}$ & $\begin{array}{l}-0.13^{*} \\
(3.29)\end{array}$ & & $\begin{array}{l}-\mathbf{- 0 . 3 2 *} \\
(7.81)\end{array}$ & \\
\hline EMIGRATION_1968_1990 & & & $\begin{array}{c}0.09 \\
(1.18) \\
\end{array}$ & & & $\begin{array}{l}0.16 * * \\
(2.17) \\
\end{array}$ & & $\begin{array}{l}0.06^{*} \\
(3.68) \\
\end{array}$ \\
\hline EMIGRATION_FTA & & & $\begin{array}{c}\mathbf{0 . 0 7} \\
(\mathbf{0 . 5 5})\end{array}$ & & & $\begin{array}{c}0.12 \\
(0.90)\end{array}$ & & $\begin{array}{l}0.16^{*} \\
(5.08)\end{array}$ \\
\hline Constant & $\begin{array}{c}-6.41 \\
(1.274) \\
\end{array}$ & $\begin{array}{l}-6.94 \\
(1.46) \\
\end{array}$ & $\begin{array}{l}-4.54 \\
(1.05)\end{array}$ & $\begin{array}{c}-18.13 * \\
(5.05) \\
\end{array}$ & $\begin{array}{l}-5.43 \\
(0.97) \\
\end{array}$ & $\begin{array}{l}-0.96 \\
(0.19) \\
\end{array}$ & $\begin{array}{c}-35.09 \\
(4.56) \\
\end{array}$ & $\begin{array}{c}1.44 \\
(0.46)\end{array}$ \\
\hline \multicolumn{9}{|l|}{ Statistics } \\
\hline Observations & 101 & 80 & 80 & 78 & 56 & 56 & 54 & 54 \\
\hline Adj. R2 & 0.93 & 0.95 & 0.92 & 0.97 & 0.86 & 0.86 & 0.95 & 0.95 \\
\hline Durbin Watson & 1.01 & 1.45 & 1.27 & 1.49 & 1.27 & 1.17 & 2.27 & 2.61 \\
\hline $\begin{array}{l}\text { LM serial correlation } \\
\left(\text { Obsvs } * R^{2}\right): P \text {-value }\end{array}$ & 0.00 & 0.01 & 0.00 & 0.002 & 0.01 & 0.00 & 0.02 & \\
\hline Adj. Dickey Fuller & $-6.10 *$ & $-5.05 * *$ & $-6.39 *$ & & $-5.74 *$ & $-4.51 * * *$ & -5.51 & -9.97 \\
\hline Phillips-Perron & $-5.72 *$ & $-6.99 *$ & $-5.80 *$ & & $-4.46 * * *$ & -4.29 & -24.89 & -26.85 \\
\hline Saikkonen (1991) adjustment & & & & 1.42 & & & 3.50 & 3.50 \\
\hline
\end{tabular}


Notes to table A1: All variables in log form, except for FIXED EXCHANGE, WWI, WWII, and WWI-AFTERMATH.

$*(* *) * * *=$ Significant at $1 \%(5 \%) 10 \%$.

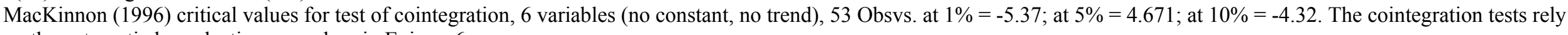
on the automatic lag selection procedure in Eviews 6.

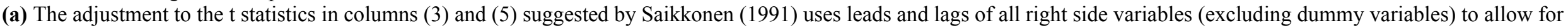

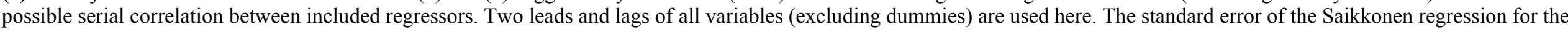

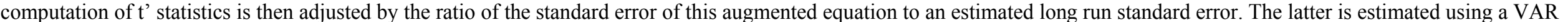
on the Saikkonen equation residuals (with no constant and 3 lags). See Hamilton (1994, 610/11) for details. 
Figure A3

Predicted Federal Government Size With and Without Emigration Restrictions, 1968 - 1990.

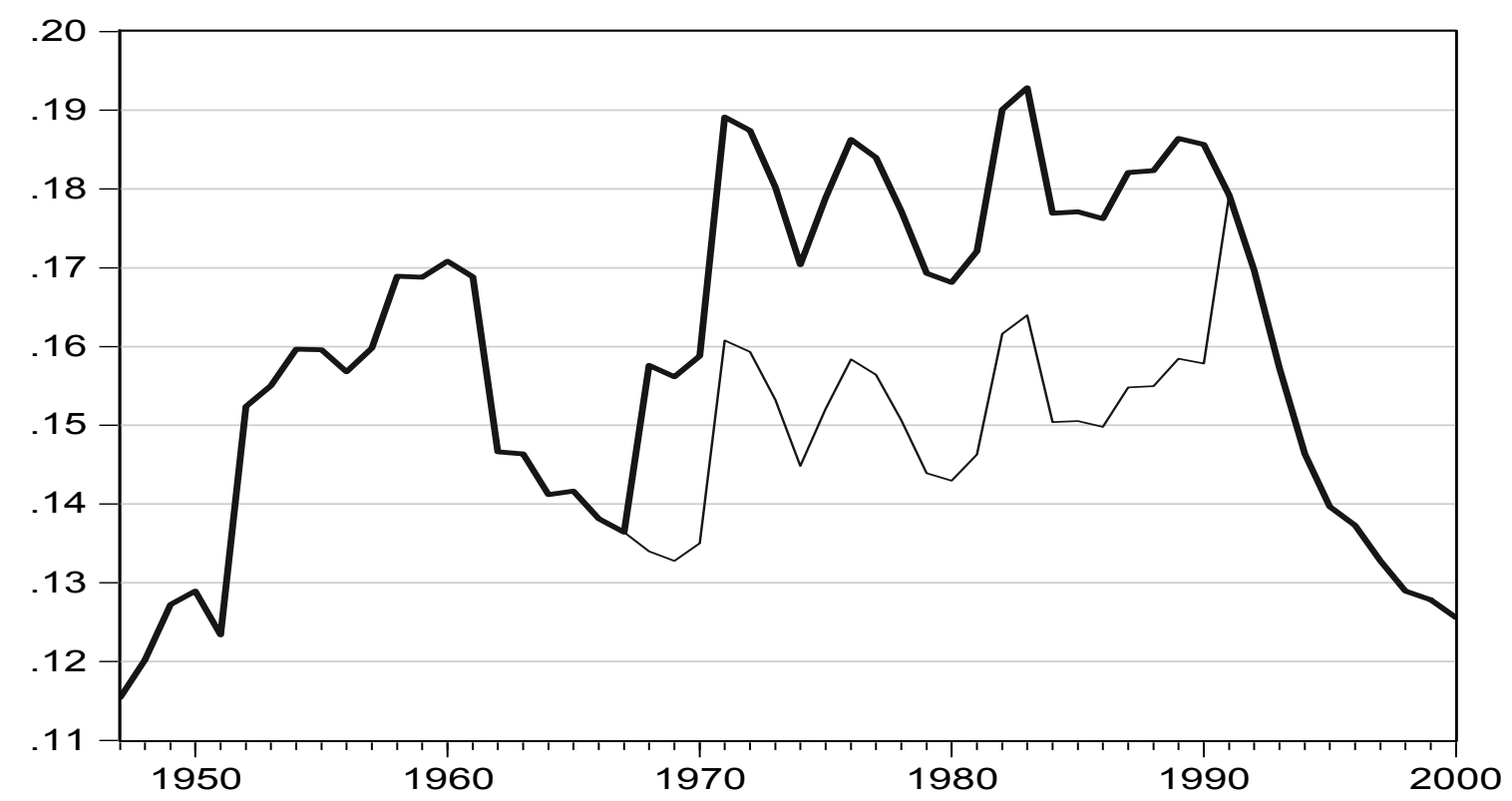

Predicted federal government size without emigration restriction 1968 - 1990 Predicted federal government size in presence of actual emigration restrictions 
Figure 1

Comprehensive Measure of Government Size:

Defense and Depreciation Adjusted with Nonprofit Hospitals and Universities Included Consistently

1929 - 2004

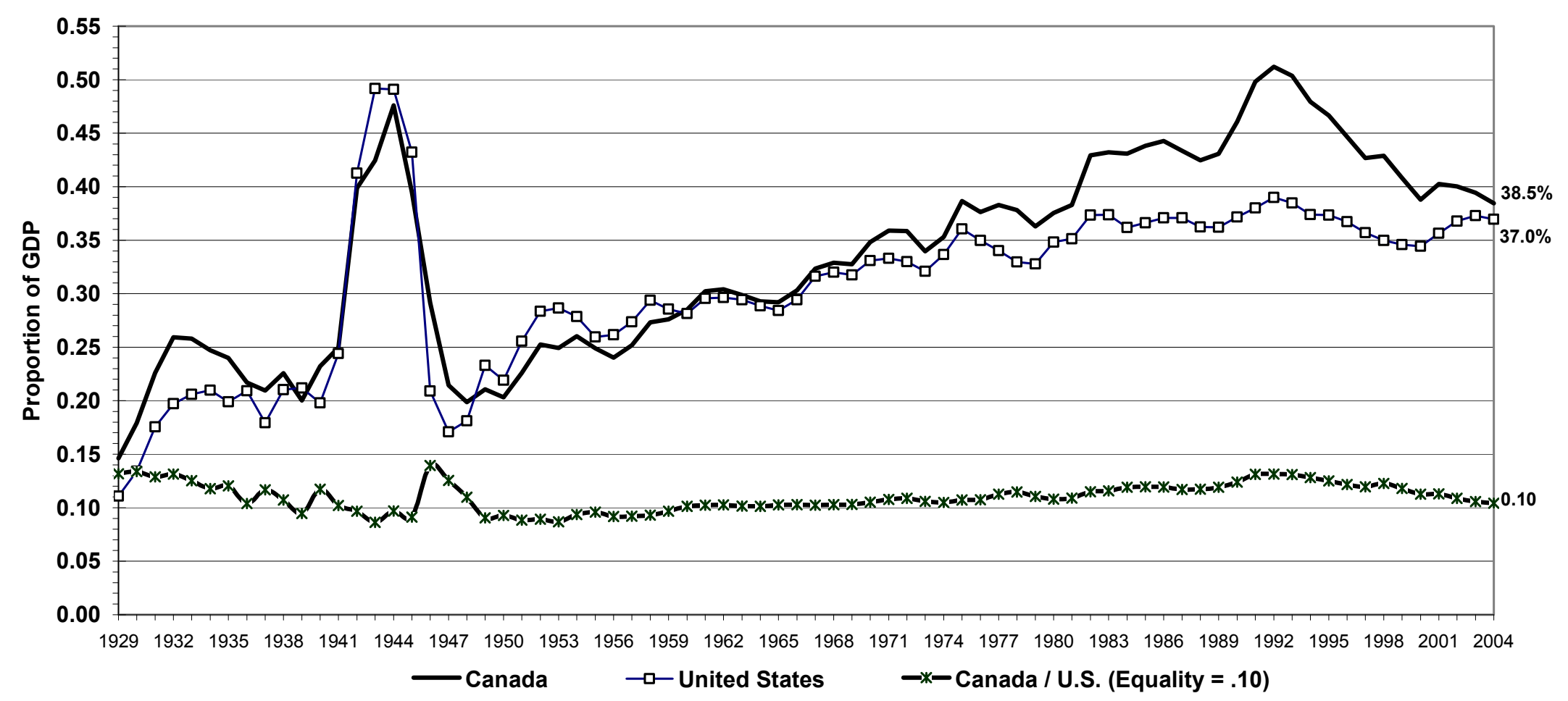

Source: Ferris and Winer (2007, Figure 8 ) 
Figure 2

Official Migrants from Canada to the United States

1946 - 2005

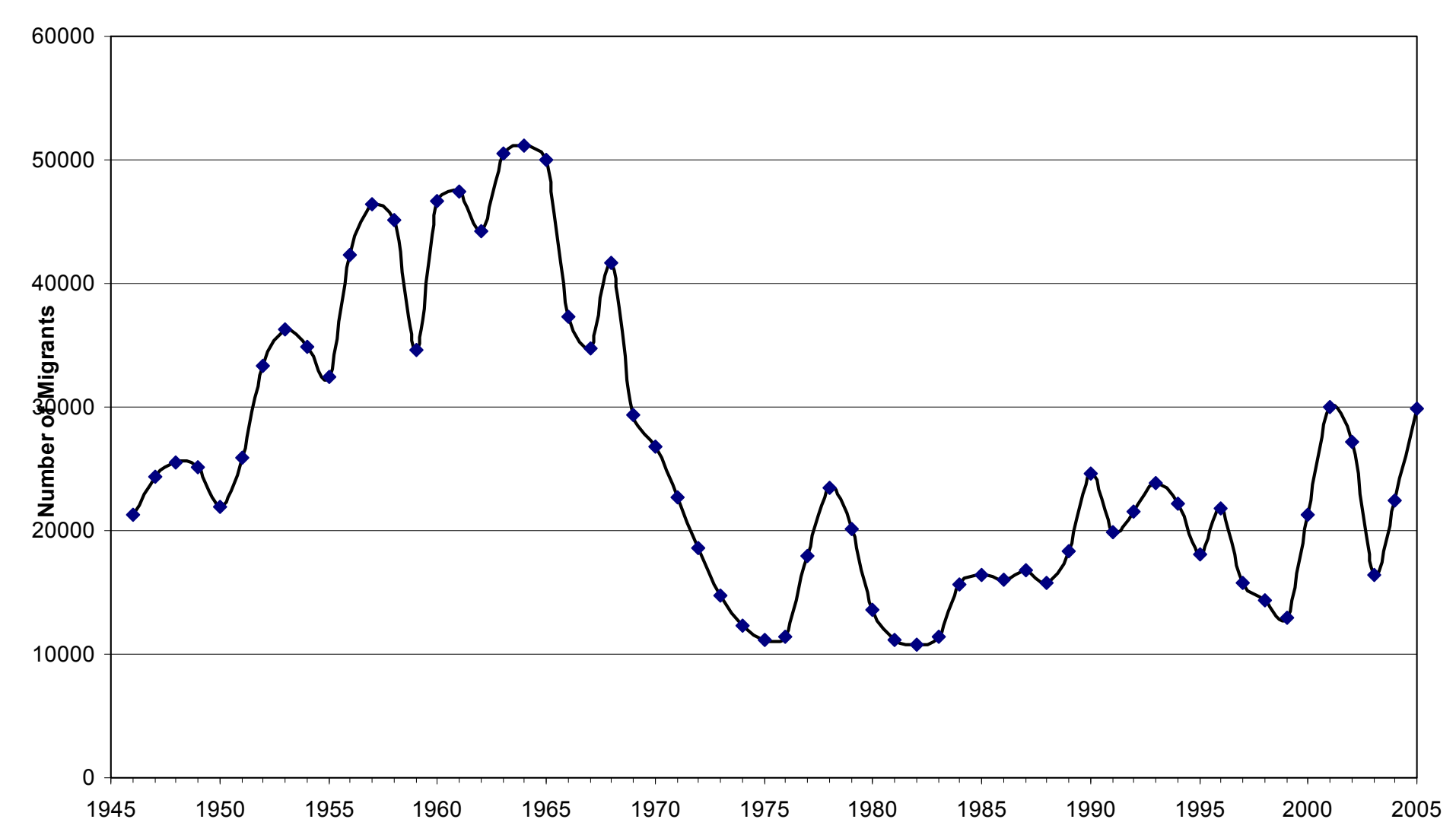

Source: Carter et al. (2006) Table Ad162-172 for 1946-1997 and Statistical Abstract of the United States, various editions, for 1998-2005. 
Figure 3

Fiscal Equilibria in a Competitive Political System Before and After the Closing of the Border

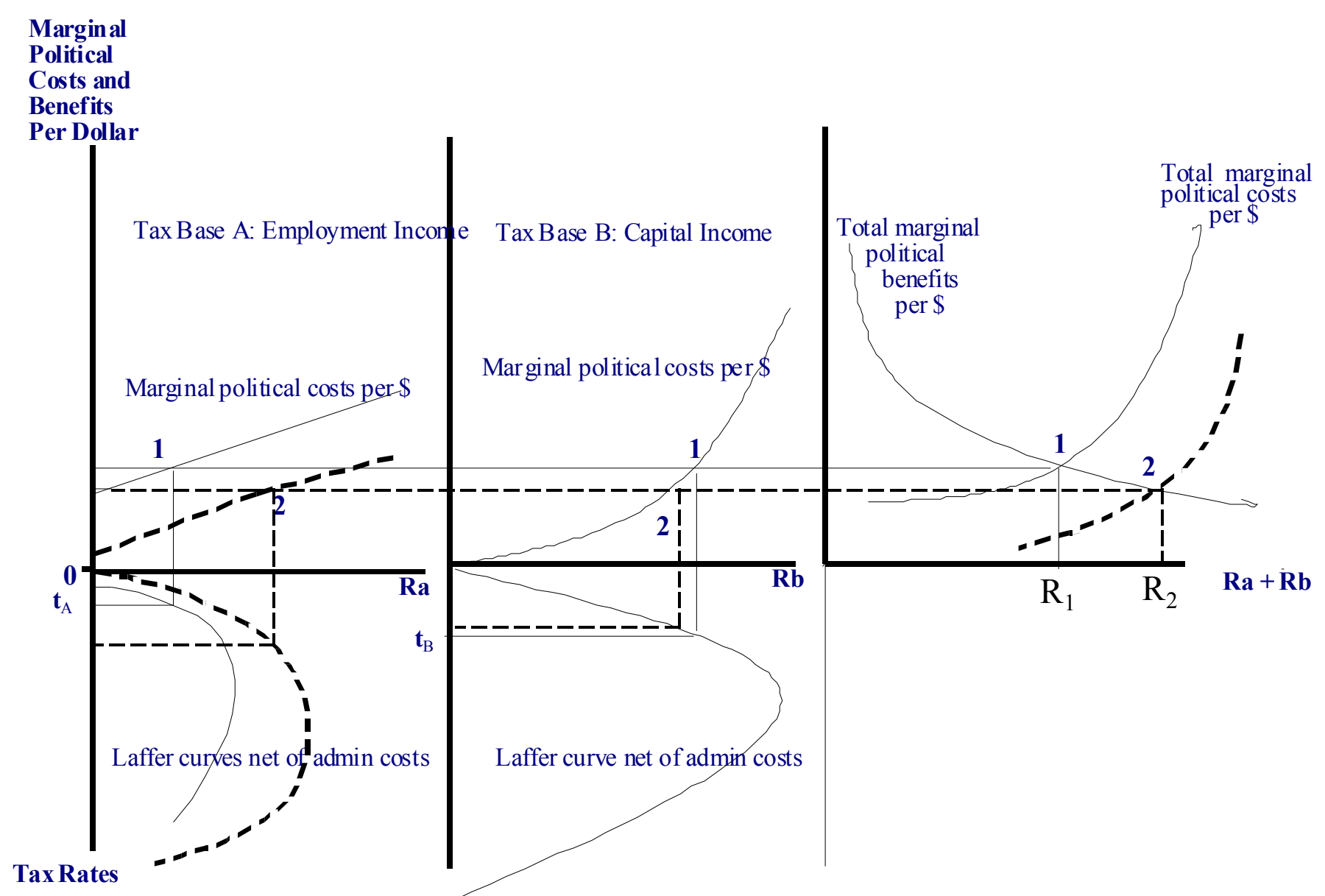


Table 1

The Tax Mix in Canada, Consolidated Public Sector, 1950 - 2000

\begin{tabular}{cccccc}
\hline \multicolumn{7}{c}{ As A Percent of Total Taxes } \\
& \multicolumn{7}{c}{ Social } \\
Year & Personal & Corporate & Insurance & Indirect & Local \\
1950 & Income Tax & Income Tax & Taxes & Taxes & Taxes \\
1960 & 15.0 & 24.3 & na & 48.4 & 12.37 \\
1970 & 21.1 & 17.0 & na & 44.9 & 17.02 \\
1980 & 34.2 & 11.6 & 7.1 & 33.1 & 14.06 \\
1985 & 35.3 & 13.3 & 9.3 & 30.3 & 11.83 \\
1990 & 35.5 & 10.4 & 11.8 & 31.6 & 10.69 \\
1995 & 40.3 & 7.1 & 12.1 & 30.0 & 10.42 \\
2000 & 37.3 & 7.8 & 14.2 & 30.3 & 10.45 \\
\hline
\end{tabular}

\begin{tabular}{ccccccc}
\multicolumn{7}{c}{ As A Percent of GDP } \\
Year & $\begin{array}{c}\text { Personal } \\
\text { Income Tax }\end{array}$ & $\begin{array}{c}\text { Corporate } \\
\text { Income Tax }\end{array}$ & $\begin{array}{c}\text { Social } \\
\text { Insurance } \\
\text { Taxes }\end{array}$ & $\begin{array}{c}\text { Indirect } \\
\text { Taxes }\end{array}$ & $\begin{array}{c}\text { Local } \\
\text { Taxes }\end{array}$ & $\begin{array}{c}\text { Total } \\
\text { Taxes }\end{array}$ \\
1950 & 3.2 & 5.2 & na & 10.3 & 2.60 & 21.4 \\
1960 & 5.1 & 4.0 & na & 10.6 & 4.00 & 23.7 \\
1970 & 10.0 & 3.4 & 2.1 & 9.7 & 4.10 & 29.3 \\
1980 & 10.2 & 3.9 & 2.7 & 8.7 & 3.40 & 28.9 \\
1985 & 10.9 & 3.2 & 3.7 & 9.7 & 3.30 & 30.8 \\
1990 & 14.1 & 2.4 & 4.3 & 10.6 & 3.70 & 35.1 \\
1995 & 13.1 & 2.7 & 5.0 & 10.6 & 3.70 & 35.1 \\
2000 & 13.4 & 4.5 & 4.6 & 10.2 & 3.10 & 35.7
\end{tabular}

Source: Calculated from Table B.4, Finances of the Nation. Canadian Tax Foundation, 2005. Numbers do not add up exactly due to rounding. 
Figure 4

Marginal Income Tax Rates, Canada, 1947 - 2000*

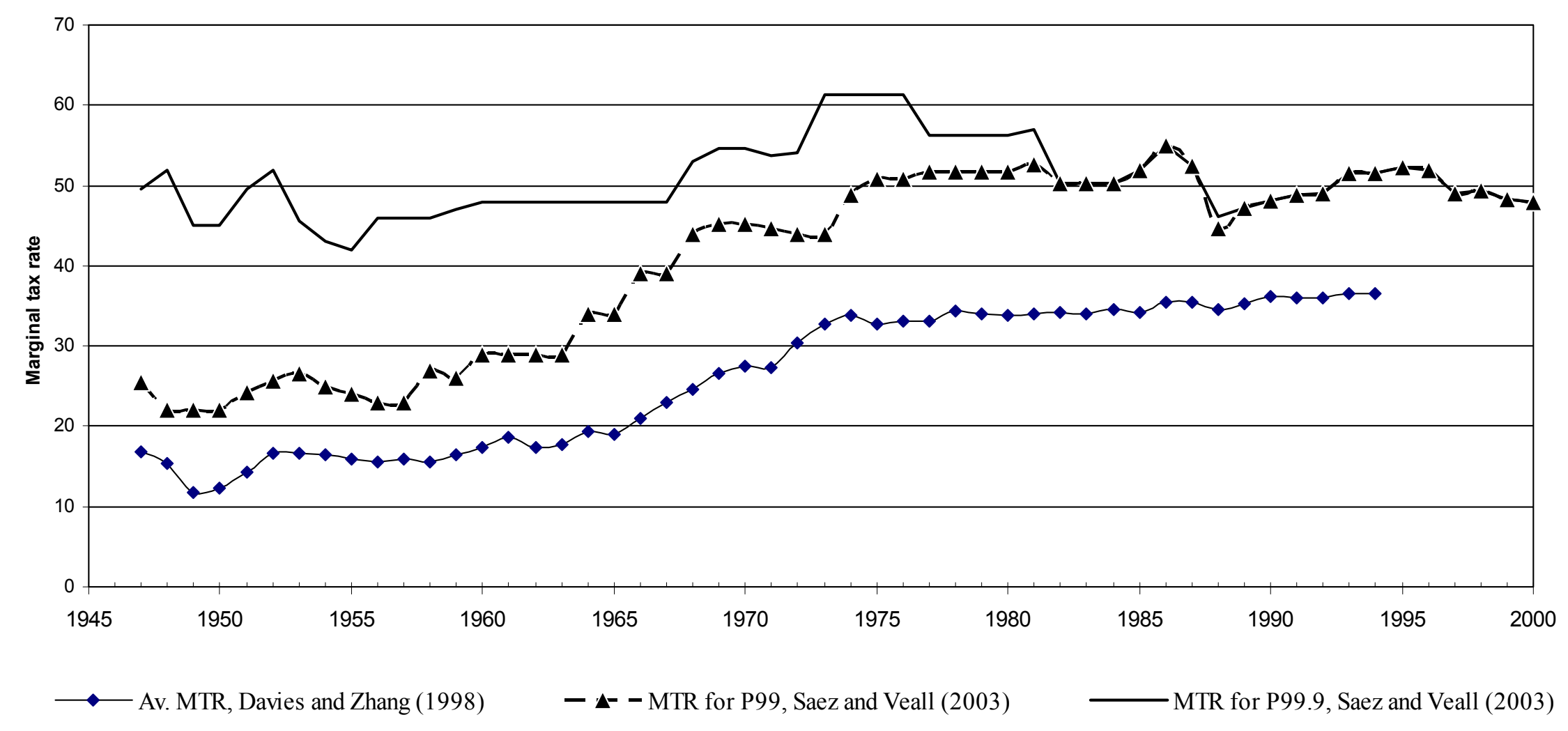

Notes: * MTR $=$ Marginal effective tax rate. $\mathrm{P} 99$ refers to the 99 th percentile tax bracket. 
Figure 5

Comprehensively Defined Non-Defence Government Spending as a Proportion of GDP 1929 - 2004

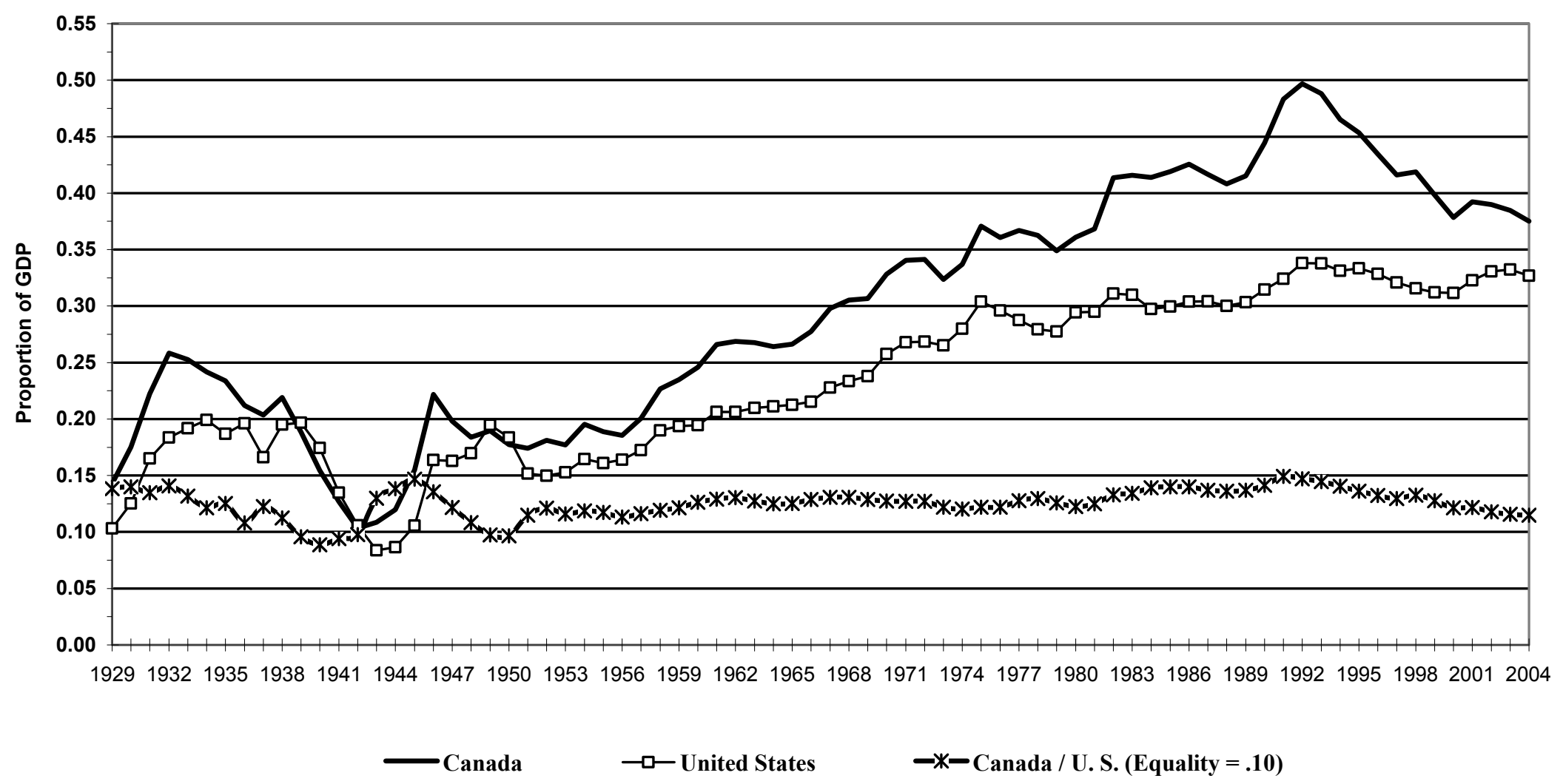

Source: Ferris and Winer (2007, Table 10b) 
Figure 6

Capital Income becomes More Sensitive to Taxation

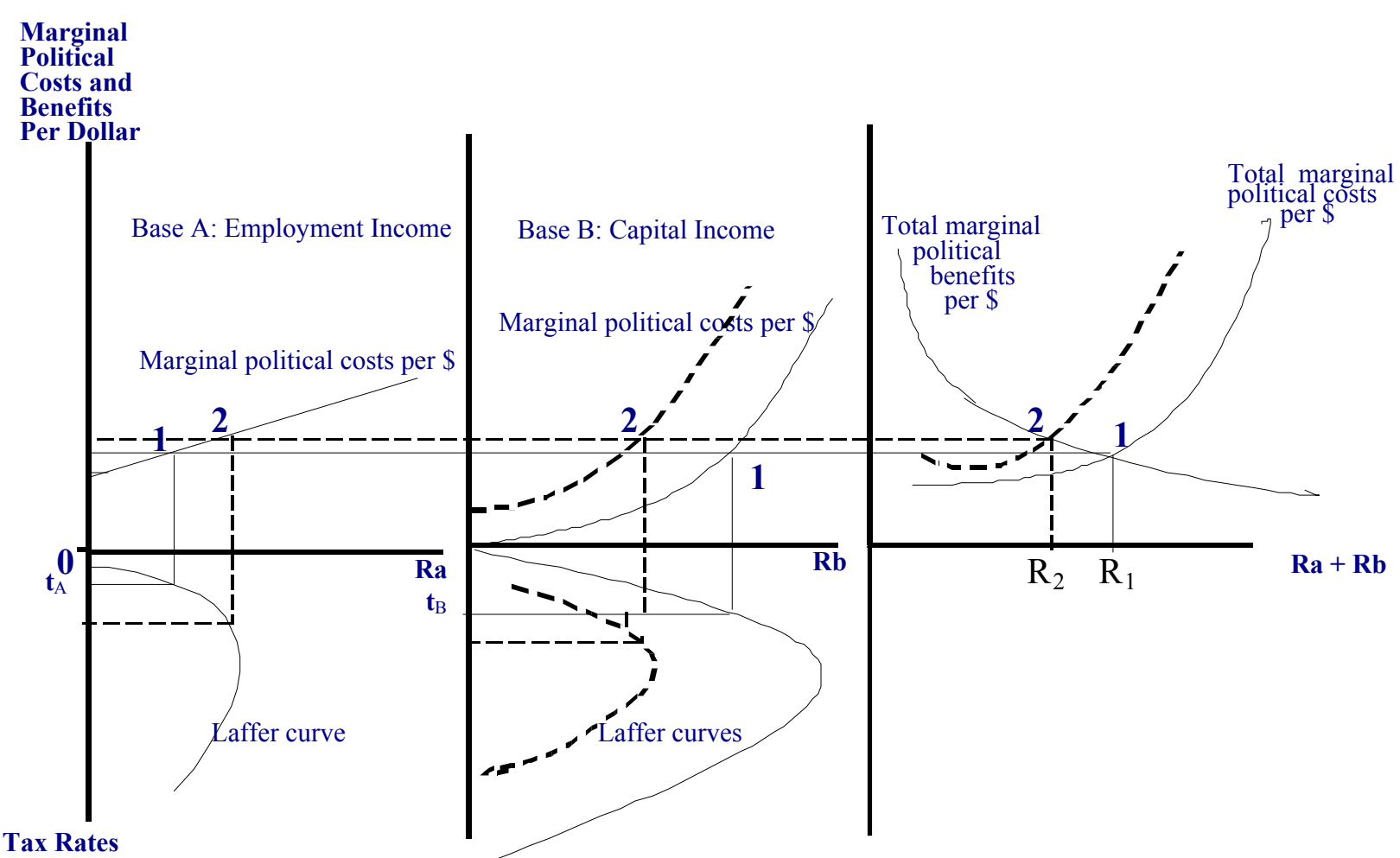

